
STUDENTS PARTICIPATING IN DESEGREGATION PROGRAMS TO THEIR PEERS

\author{
A Dissertation in Practice \\ presented to \\ the Faculty of the Graduate School \\ at the University of Missouri-Columbia \\ In Partial Fulfillment \\ of the Requirements for the Degree \\ Doctor of Education \\ by \\ AMANDA M. LEWIS \\ Dr. Paul Watkins, Dissertation in Practice Supervisor \\ MAY 2018
}


(C) Copyright by Amanda M. Lewis 2018

All Rights Reserved 
The undersigned, appointed by the dean of the Graduate School, have examined the dissertation entitled:

\section{A COMPARISON OF THE SOCIAL AND ACADEMIC IMPACT OF HIGH SCHOOL STUDENTS PARTICIPATING IN DESEGREGATION PROGRAMS TO THEIR PEERS}

presented by Amanda M. Lewis,

a candidate for the degree of Doctor of Education

and hereby certify that, in their opinion, it is worthy of acceptance.

Dr. Paul Watkins, Major Advisor

Dr. William Bratberg

Dr. Bret Cormier

Dr. Margaret Dalton

Dr. David Stader 


\section{Dedication}

To my husband Zach, thank you so much for being my rock through this process. Your unwavering support was appreciated and often gave me the motivational push that I needed. Thank you for caring for the kids and me. I love you so very much.

To my children Ansley, Grady, and Beckett, thank you for loving me unconditionally

through my classes. It was hard on this mama to miss your games and events, and I know it was hard on you too. I am proud of many of my accomplishments, but I am most proud of each of you.

To my family and friends, thank you for listening - to my ideas, my passions, and my whining. I truly appreciate everyone willing to step in and help as we juggled very busy schedules over the past three years.

To my parents, thank you for instilling a strong work ethic and passion for learning. I appreciate your support throughout the years. I love you. 


\section{ACKNOWLEDGEMENTS}

To Dr. Paul Watkins, thank you for your passion and dedication, feedback and support throughout coursework. I enjoyed listening and learning during our class discussions. Your humor and life experiences added a layer to our class that I truly appreciated.

To all Cohort 10 professors, thank you for enthusiastically sharing your areas of curricular expertise during our summer sessions. I believe that I am a better practitioner because of this process.

To the members of my dissertation committee, Dr. Paul Watkins, Dr. William Bratberg, Dr. Margaret Dalton, and Dr. David Stader, thank you for your time and direction throughout the dissertation process.

To my coworkers, thank you for your support and encouragement throughout the doctoral coursework and the writing process. You are truly appreciated.

Finally, to my Cohort 10 classmates, thank you for the laughter and support. I am blessed to have each of you in my life. 


\section{TABLE OF CONTENTS}



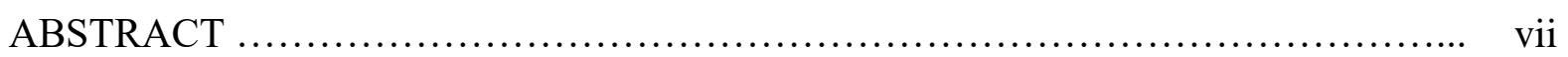

\section{Chapter}

1. INTRODUCTION TO DISSERTATION IN PRACTICE ................... 1

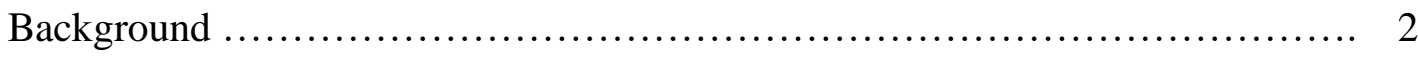

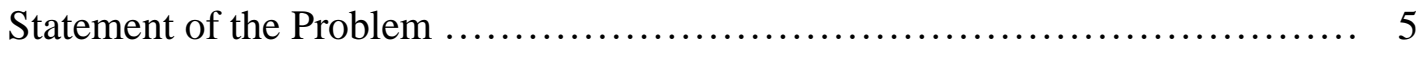

Purpose of the Study .............................................. 6





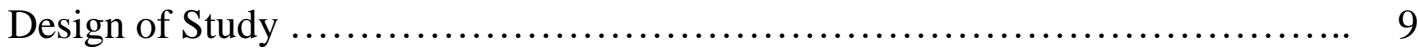

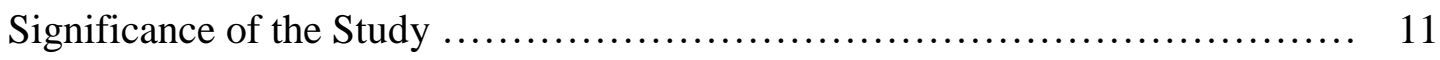

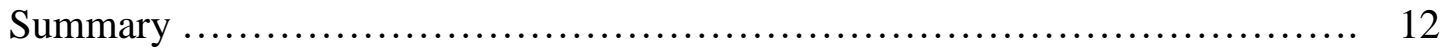

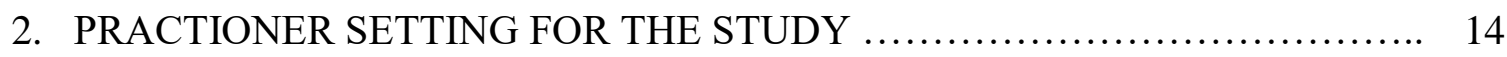

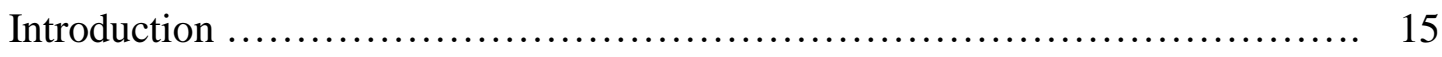

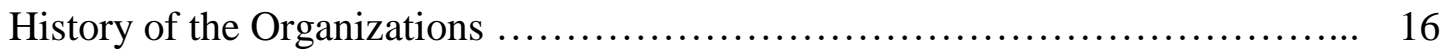

Voluntary Interdistrict Choice Corporation ....................... 16

Suburban School District ..................................... 17

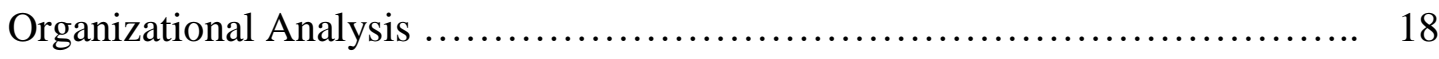

Voluntary Interdistrict Choice Corporation ....................... 18

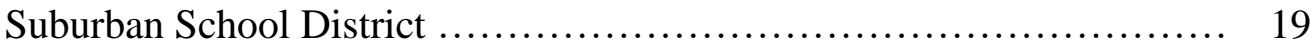

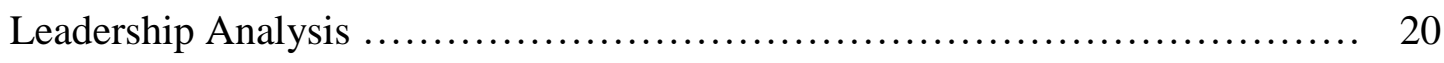

Voluntary Interdistrict Choice Corporation $\ldots \ldots \ldots \ldots \ldots \ldots \ldots \ldots \ldots \ldots . . \ldots \ldots$ 
Implications for Research ......................................... 22

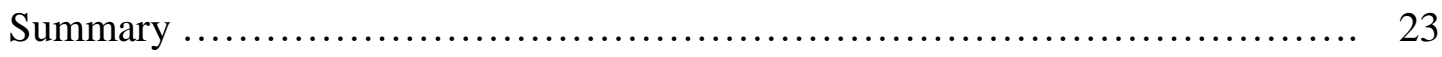

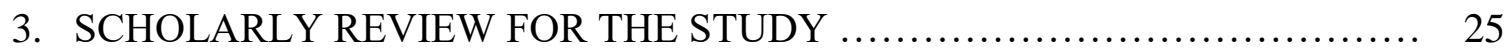

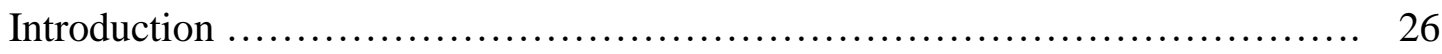

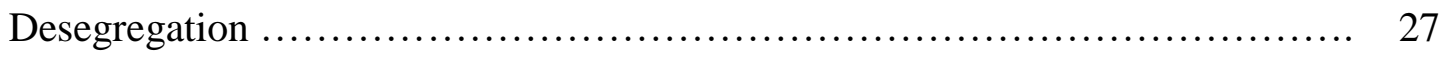

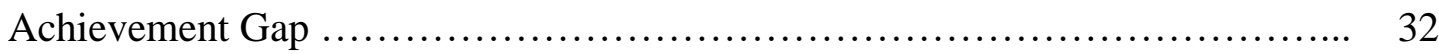

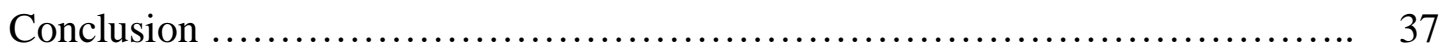



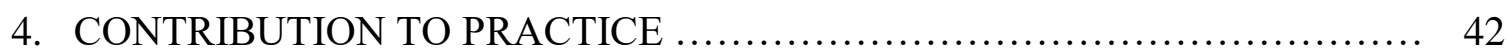

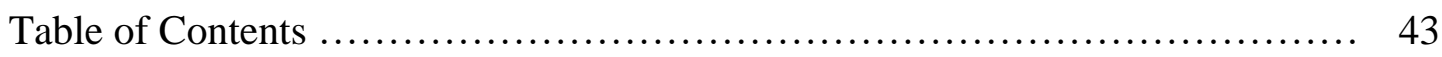

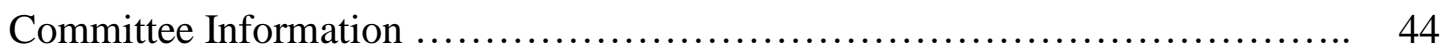



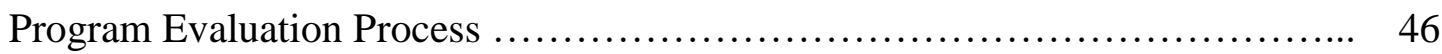

Research Questions and Hypotheses ............................ 48

Current Definition of the VICC Program ............................ 49

Current Status of the VICC Program $\ldots \ldots \ldots \ldots \ldots \ldots \ldots \ldots \ldots \ldots \ldots \ldots \ldots .50$

Strengths and Concerns for the VICC Program ......................... 51

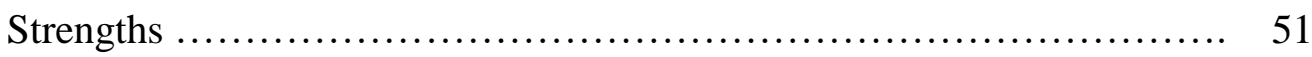

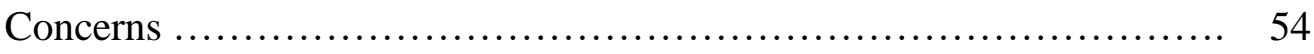

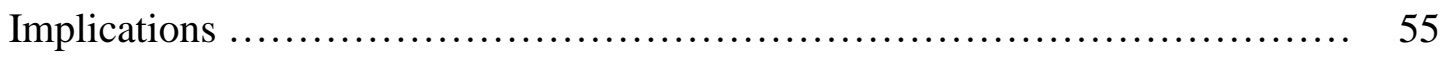

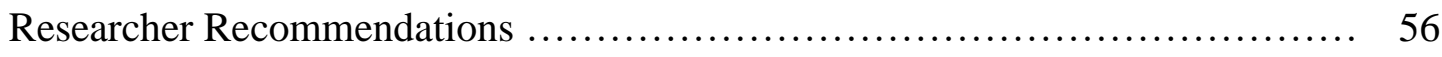

Recommendations for Leadership ............................. 57 
Recommendations for Program Implementation and Education

Recommendations for Program Monitoring …...................... 59

Conclusion .................................................................. 60

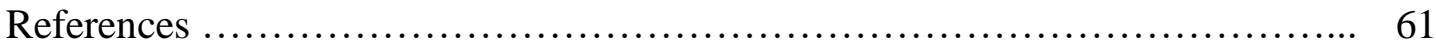

5. CONTRIBUTION TO SCHOLARSHIP .................................... 63

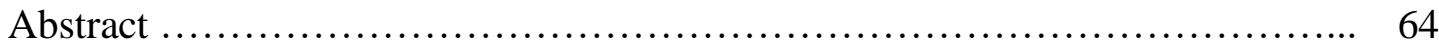

Research Questions and Hypotheses .................................... 66

Social Justice and Equity in Education ................................... 68

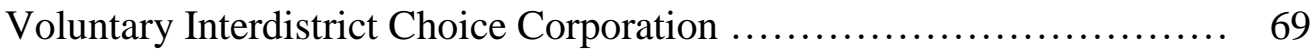

Achievement Gap ............................................. 70

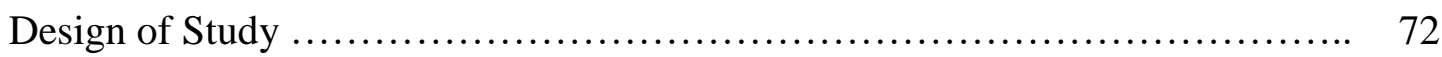

Participants ................................................... 75

Data Collection Tools ........................................... 75

Data Analysis ................................................... 76

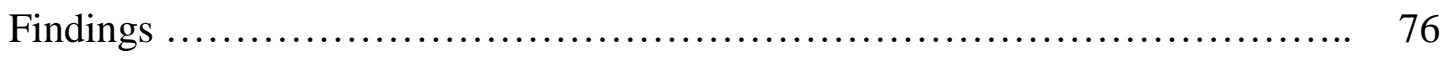

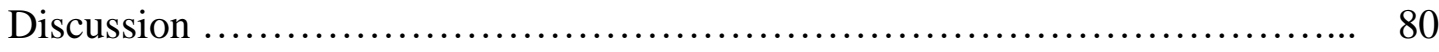

Limitations ............................................................... 82

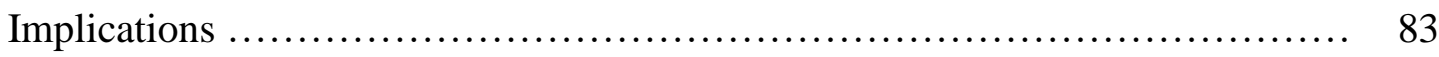

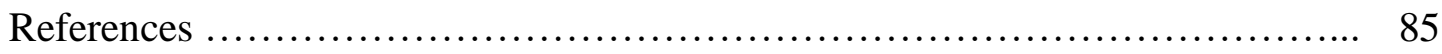

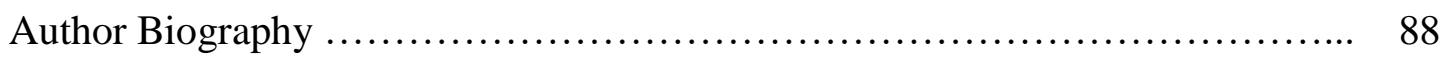

6. SCHOLARLY PRACTIONER REFLECTION ............................. 89

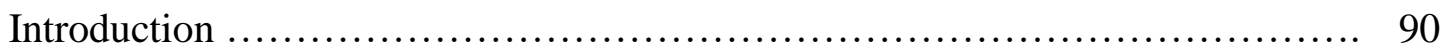

Influence as an Educational Leader ....................................... 90 
Influence as a Scholar

BIBLIOGRAPHY

APPENDIX 


\title{
A COMPARISON OF THE SOCIAL AND ACADEMIC IMPACT OF HIGH SCHOOL STUDENTS PARTICIPATING IN DESEGREGATION PROGRAMS TO THEIR PEERS
}

\author{
Amanda M. Lewis \\ Dr. Paul Watkins, Dissertation in Practice Advisor
}

\begin{abstract}
The purpose of this quantitative study was to compare the social and academic impact data of African American students enrolled in the St. Louis city desegregation program, the Voluntary Interdistrict Choice Corporation (VICC), to their peers attending neighborhood district schools. The research specifically analyzed student data for grades 9-12 from two area school districts, one St. Louis city district and one county district. Attendance rates, drop-out rates, graduation rates, ACT scores, and EOC scores were examined to determine if enrollment in the desegregation program had a positive or negative impact.

Study results found a statistically significant positive relationship between students enrolled in the VICC desegregation program and the social areas of attendance rates, drop-out rates, and graduation rates. A statistically significant positive relationship was also found between students enrolled in the desegregation program and the academic areas of ACT and EOC scores. Academic area data was closer in comparison than social data. However, the relationship continued to show a positive statistical significance among VICC students.
\end{abstract}




\section{CHAPTER ONE:}

INTRODUCTION TO DISSERTATION IN PRACTICE 


\section{Background}

In 1954, Supreme Court Justice, Earl Warren, penned the court's decision in the case of Brown v. the Board of Education of Topeka. He wrote, "We conclude that, in the field of public education, the doctrine of 'separate but equal' has no place. Separate educational facilities are inherently unequal" (Lawrence, 2012). As our nation approaches nearly 65 years of integration in education, an achievement gap continues to exist. Why? If all students are able to access the same level of education and resources for learning, shouldn't students be learning at the same rate? If our schools are fully integrated, why do programs designed to encourage integration within our communities continue to not only exist, but receive state and federal funding or contributions from private entities?

In the city of St. Louis, Missouri, African American students have several options when it comes to their education. Students can choose to attend schools within their neighborhood district, magnet or charter schools, or enroll in the city's desegregation program, the Voluntary Interdistrict Choice Corporation (VICC). Each year, new VICC students are selected from a lottery to join the approximate 4,000 students attending participating St. Louis County elementary, middle, and high schools located within a 30-mile radius from their homes (VICC, 2017). Students enrolling with VICC must understand the requirements of the program and be willing to commit to an altered school day compared to their peers attending schools near home. A typical day for VICC students begins with a 40 to 75 -minute bus ride to school. These young men and women attend classes all day, then frequently stay after school for extra help on assignments before returning home in the late afternoon. Middle and high school students selecting to participate in extracurricular sports or activities ride the evening school bus or take a taxicab home, sometimes arriving after 9:00 pm. They eat dinner, complete homework, and wake up the following morning to repeat the entire process. Students participating in desegregation 
programs dedicate a tremendous amount of time to attend schools outside of their neighborhood school districts. Has the VICC desegregation program had a positive social and academic impact on participating students?

The research in this document is designed to provide a greater understanding of the effectiveness of desegregation programs by offering a comparison of the social and academic impact data between students enrolled in a desegregation program, specifically in St. Louis County, Missouri, with students enrolled in their home schools within the Urban School District (USD) in the city of St. Louis, Missouri. Using quantitative research methods, the researcher will present findings in the form of strengths and concerns comparing social and academic impact data. The intent, upon conclusion of the study, is to present findings to the education community with recommendations for future development to further close the academic achievement gap.

Desegregation programs in the United States were gradually introduced following civil rights efforts beginning with the 1954 court case, Brown v. the Board of Education of Topeka. Linda Brown, an African American elementary student in Topeka, Kansas, was made to walk through a railroad switchyard to get to her bus stop, while passing an all-white elementary school close to her home. Her parents petitioned the court for Brown to attend the all-white school stating that the segregation of the schools was violating their $14^{\text {th }}$ amendment rights, as African American students did not have equal educational opportunities compared to their white counterparts (Landmark Cases, 2017). The Supreme Court determined that "separate but equal" was unconstitutional. African American students should have the opportunity to attend schools in their neighborhoods, as well as access resources to enhance their educations (Epps-Robertson, 2016). The ruling overturned an 1896 Supreme Court decision in Plessy v. Ferguson, stating that 
it was lawful for states to require racial segregation of public facilities, including schools (McCarthy, 2015).

Integration was further encouraged by the Civil Rights Act of 1964, or Title VI, which threatened to revoke funding from schools choosing not to comply with desegregation processes (McCarthy, 2015). The hope of desegregation was to provide students of color with more options and equal opportunity for a better education; and to create a better environment and community structure within the cities themselves. Ultimately, the lack of housing affordability and movement of community members perpetuated the existence of a segregated society (Miyasaki, 2015). The achievement gap that was created during a time of segregation continued to grow wider.

In 1980, the U. S. Court of Appeals upheld a 1972 lawsuit stating that the State of Missouri and the Urban School District Board of Education were accountable for perpetuating a segregated school system. In 1983, a settlement agreement was created allowing for African American students residing in the city of St. Louis to attend participating schools within St. Louis County, while encouraging white students in St. Louis County to attend magnet schools in the city of St. Louis (VICC, 2017). The State of Missouri agreed to cover the cost of program and established a goal of achieving an African American population of $25 \%$ in the St. Louis County schools. In 1999, the non-profit, Voluntary Interdistrict Choice Corporation (VICC), was recognized as the manager of the desegregation program through the intended close of the program in the 2008-2009 school year. VICC leaders voted for extension of the program multiple times beyond the intended close date. In 2016, the Board of Directors for the VICC program officially announced that they would no longer accept new students as of the 2023-2024 school year. Students already enrolled in the program and attending participating county schools 
would be able to continue through their graduation years. When all students have graduated, the VICC desegregation program will be terminated (VICC, 2017).

\section{Statement of the Problem}

Very little information can be found in the literature regarding the social and academic impact of students participating in desegregation programs compared to their cohort of peers attending schools within their assigned neighborhood school districts. Several different avenues of research could potentially lead to an understanding as to whether or not a significant difference of social and academic impact exists between the two groups. The researcher could focus on the social and academic impact data of students enrolled in desegregation programs compared to their home school district. The researcher could also evaluate whether or not an achievement gap exists between students enrolled in magnet schools versus their home school district. Additionally, the researcher could focus on access to educational resources in schools participating in desegregation programs compared to those not involved or the social/emotional effects of desegregation. The research could go beyond the K-12 environment to explore the success of students in their post-secondary endeavors, including but not limited to postsecondary school enrollment and employment opportunities.

This particular study will focus on the gap in literature surrounding the social and academic impact of students in grades 9-12 enrolled in a desegregation program, specifically the Voluntary Interdistrict Choice Corporation (VICC) in St. Louis, Missouri. The study will compare this data to their peers in grades 9-12 attending schools within Urban School District in St. Louis, Missouri; and indicate whether participation in the VICC program had a positive or negative effect on the social and academic success of students. Information indicates the VICC program was designed to desegregate the Urban School District and school districts within St. Louis County in order to provide a fair education for African American students, while 
encouraging the integration of the surrounding communities. However, a minimal amount of information exists detailing the effect of the desegregation program on the students' social and academic progress since the inception of the program.

\section{Purpose of the Study}

The purpose of this study is to provide a comparison of the social and academic impact of African American students in grades 9-12 participating in the Voluntary Interdistrict Choice Corporation desegregation program to their non-participating peers. This information will be shared with the student's assigned schools within their neighborhood school district, Urban School District, in St. Louis, Missouri. It will also be shared with a St. Louis County school district, Suburban School District, participating in the VICC program.

The St. Louis, Missouri, desegregation program was established in 1983. In 1999, the non-profit, Voluntary Interdistrict Choice Corporation (VICC), took over the management of the program with the intention of closing enrollment within 10 years. Instead, the VICC board of directors voted to extend enrollment through the 2023-2024 school year, allowing students already established as participants of the program to continue through graduation (VICC, 2017). This information could lead to the assumption that the experience and/or achievement of students enrolled in the desegregation program was positive when compared to their peers. If the VICC program has been successful over the past 34 years and received extensions for enrollment, why would the Board of Directors choose to discontinue the program now? The hope for this research is to provide a clearer understanding as to whether participation in the VICC desegregation program has a positive or negative social and academic impact on African American students attending schools in St. Louis County compared to students attending schools in the Urban School District. 


\section{Research Questions and Hypotheses}

There are five main research questions guiding this study, with each question focusing on specific social and academic impact data. The questions and hypotheses are as follows:

Q1: What is the difference in the attendance rates of African American students in grades 912 enrolled in the Voluntary Interdistrict Choice Corporation desegregation program, as compared to students in grades 9-12 enrolled in the Urban School District?

H1: It is predicted that the attendance rates will show a positive statistical significance for VICC students attending Suburban School District (SSD) high schools.

Q2: What is the difference in the graduation rates of African American students in grades 912 enrolled in the Voluntary Interdistrict Choice Corporation desegregation program, as compared to students in grades 9-12 enrolled in the Urban School District?

$\mathrm{H} 2$ : It is predicted that the graduation rates will show a positive statistical significance for VICC students attending Suburban School District high schools.

Q3: What is the difference in the drop-out rates of African American students in grades 9-12 enrolled in the Voluntary Interdistrict Choice Corporation desegregation program, as compared to students in grades 9-12 enrolled in the Urban School District?

H3: It is predicted that the drop-out rates will show a positive statistical significance for VICC students attending Suburban School District high schools.

Q4: What is the difference in the ACT scores of African American students in grades 9-12 enrolled in the Voluntary Interdistrict Choice Corporation desegregation program, as compared to students in grades 9-12 enrolled in the Urban School District?

H4: It is predicted that the ACT scores will show a positive statistical significance for VICC students attending Suburban School District high schools.

Q5: What is the difference in the End-of-Course (EOC) exam scores of African American 
students in grades 9-12 enrolled in the Voluntary Interdistrict Choice Corporation desegregation program, as compared to students in grades 9-12 enrolled in the Urban School District?

H5: It is predicted that the EOC scores will show a positive statistical significance for VICC students attending Suburban School District high schools.

\section{Theoretical Framework}

The lens used to frame this research is focused on social justice with an emphasis on equity in education. Martin \& Ngcobo (2015) define social justice as the "full and equal participation of all groups in society that is mutually shaped to meet their needs" (p.89). As our society continues to challenge practices and procedures to be more accepting and inclusive of all citizens, there is still much work that needs to be done. Logan (2016) states, "high school segregation persists in the United States despite attempts to desegregate schools...after the Brown vs Board of Education decision" (p. 324). Although many schools have diverse populations, they continue to face the difficult challenge of learning, understanding, and implementing components of desegregation. Educators have to be willing to develop curriculum that maintains respectful acceptance among students while providing a solid and inclusive learning environment that will help to close the achievement gap (Welton, 2013). Unintentional segregation continues to exist in many areas of our country, and the achievement gap continues to plague our students. (McCarthy, 2015).

"The racial achievement gap reflects the inequality in educational experience" (Chu, 2011, p. 202). State education systems have implemented programs to integrate students in order to close the achievement gap. The question is whether or not these programs are working effectively (McCarthy, 2015). Students participating in the VICC desegregation program in St. Louis, Missouri, have accessed a learning environment and resources different than their peers 
attending Urban School District. Does this have an effect on their social and academic success or on the achievement gap? This study provides comparative data that has not been published prior within an academic article. The research is intended to lead the reader to a greater understanding as to whether or not funding the VICC program has a significant social and academic impact on students and the effectiveness of closing the achievement gap. Should the VICC desegregation program continue?

\section{Design of the Study}

In an attempt to further understand the social and academic impact of students enrolled in the VICC program compared to their peers enrolled in their neighborhood school district, Urban School District, the researcher will complete a quantitative study. Information will be obtained from three main sources: 1) the Missouri Department of Elementary and Secondary Education, 2) the Voluntary Interdistrict Choice Corporation, and 3) the Suburban School District, VICC program participant. This section will outline the participants, setting for research, and data collection process.

The research within this study will compare the social and academic impact data of two core groups of students. They are: 1) students in grades $9-12$ within the city of St. Louis, Missouri, enrolled in 3 traditional high schools in Urban School District, and 2) African American students in grades 9-12 from the city of St. Louis, Missouri, enrolled in the VICC desegregation program and attending St. Louis County high schools in Suburban School District. According to the Missouri Department of Elementary and Secondary Education (DESE) (2017), the Urban School District enrolled 24,496 pre-school through $12^{\text {th }}$ grade students in 2016 . The district is comprised of 74 public, magnet, and alternative schools; further defined as 45 elementary schools, 9 middle schools, 14 high schools, and 6 alternative schools. Eighteen of 
these schools enroll students in grades 9 - 12. However, only 3 high schools are considered traditional public schools. The other 15 are alternative, technical, or college-prep (SLPS, 2017).

In 2016, the VICC program enrolled 4,471 students in kindergarten through $12^{\text {th }}$ grade in one of 11 participating St. Louis County school districts (VICC, 2017). Families interested in enrolling their students in the VICC program must submit an application by June $30^{\text {th }}$ for the upcoming school year. Parents and students can list three districts of interest for placement purposes. Placement is first determined by availability, then VICC officials determine the appropriate school in the assigned district based on the student's address within the city of St. Louis. VICC divides the city into three attendance areas or zones. Zone one contains addresses from the northeast boundary to mid-northwest boundary, not including downtown St. Louis. Zone two contains addresses from the mid-northwest boundary to the eastern edge, including downtown St. Louis. Zone three contains addresses for the entire southern section of the city, not including the downtown area. School districts receiving students from all three attendance areas have specific schools assigned per zone for ease of transportation, which is provided for free to families through state funding (VICC, 2017). If a family enrolled in the VICC program relocates to another residence within the city of St. Louis, the student will remain enrolled. However, the student will have to attend the school assigned to that particular address and may result in the student being reassigned to another district within St. Louis County.

This study will review longitudinal data for three consecutive school years: 2014-2015, 2015-2016, and 2016-2017. Social and academic data will be obtained from the Missouri Department of Elementary and Secondary Education and the Suburban School District data department. The researcher will utilize DESE in order to access school district report card data for attendance rates, graduation rates, drop-out rates, ACT scores and EOC scores for students in 
Urban School District. The same data for VICC students enrolled in Suburban School District will be obtained from the district data department. However, this information will need to be further analyzed in order to separate data for African American students enrolled in the VICC program from non-VICC African American students who reside in St. Louis County.

Student enrollment numbers for the three focus years of the study will be evaluated using inferential statistics. The results will be displayed in a table for ease of comparison. Social and academic data will be analyzed using the IBM software program, Statistical Package for the Social Sciences (SPSS). The researcher will use the one-way ANOVA feature of SPSS to compare means of the independent variables. This will determine whether or not a statistically significant difference between the data exists. Comparison tables for each data set will expedite the analysis of social and academic data for educators and stakeholders. The researcher will also utilize descriptive statistics as an additional method of exploring data through comparison of the mean, median, mode, and sum of squares. Once all analysis is complete, the researcher will share data results with educational stakeholders in the Voluntary Interdistrict Choice Corporation, Urban School District, Suburban School District, the Missouri Department of Elementary and Secondary Education, and the education community.

\section{Significance of the Study}

The intent of this study is to provide relevant and significant information comparing social and academic impact data between two student groups from similar backgrounds attending differing educational environments. As there is currently a minimal amount of literature available, the researcher would like to contribute findings in a detailed manner to the educational community in St. Louis and across Missouri. At this time, the results of the comparison study are unknown. However, the hope is that data and findings will be used to drive best practices among 
educators in order to provide students across the state of Missouri with equal access to rigorous curriculum being taught by qualified staff with more than adequate resources.

In the fall of 2016, the Voluntary Interdistrict Choice Corporation board of directors announced plans for the termination of their 30+ year desegregation program (VICC, 2017). The 2023-2024 school year will mark the final year for new enrollees into the program. However, only a limited number of siblings of current VICC students will be allowed to enroll between 2018 and 2024. All students enrolled in the VICC program will be provided the opportunity to continue through their graduation year. The information distributed within this study will hopefully provide the researcher, reader, educational community, and policy makers with a stronger understanding of the successes or failures of this particular desegregation program within the City of St. Louis and St. Louis County, as measured by attendance rates, drop-out rates, graduation rates, ACT scores, and EOC scores. If research data reveals a positive impact from the VICC program, the researcher will provide suggestions for continuing a desegregation program that is beneficial to students in the community. However, if the program is not successful, the researcher will provide information as to why the program was not beneficial, along with practices for a successful transition of students back to their home schools within the Urban School District.

\section{Summary}

The VICC program was created with the purpose of desegregating schools and surrounding communities, while providing students in the city of St. Louis, Missouri, with a diverse education. After 34 years, the VICC board of directors announced that they will no longer accept new students into the program as of the 2023-2024 school year (VICC, 2017). Students will be able to attend their assigned St. Louis County school through their graduation year. Once all students have graduated, the VICC program will officially end. 
Although desegregation programs continue to exist throughout the United States, literature suggests that inequity continues among our schools across the country, and the achievement gap between Caucasian and African American students remains. Why? The research in this study is designed to compare the social and academic impact data of students enrolled in their neighborhood school district, Urban School District, with students enrolled in the Voluntary Interdistrict Choice Corporation desegregation program in Suburban School District. The purpose of the study is to provide a solid understanding of the participants, the setting in which the education is accessed, and the social and academic impact of students in Urban School District compared to African American students enrolled in the VICC program attending participating schools within Suburban School District in St. Louis County. The intent is to determine whether or not a significant impact on student learning exists among students enrolled in the VICC program, and provide data on the successes or failures of this particular desegregation program.

The conclusion of the study will result in a comparison of graduation rates, drop-out rates, attendance rates, ACT scores, and EOC scores of students attending Urban School District high schools versus African American students attending Suburban School District high schools through the VICC program. The information gathered will provide the researcher, as well as education community, with knowledge of inferential and comparison data among participating county schools in the VICC program to assist in further understanding the success of students. Furthermore, evidence will prove whether or not the VICC desegregation programs is beneficial to students. 
CHAPTER TWO:

PRACTITIONER SETTING FOR THE STUDY 


\section{Introduction}

St. Louis, Missouri, has a long-standing history of segregation among members of the community. Taylor (2013) states that "while the rate of segregation in the region has declined over the last thirty years, $71 \%$ of either black or white residents would have to move in order to live in a residential tract that is reflective of the region's racial composition" (p. 184). In an effort to desegregate the community and provide students with similar levels of education, a group of parents filed a class action lawsuit in 1972 requesting that students in St. Louis city receive the same level of academic rigor and resources as students in St. Louis County. Unfortunately, a segregated system and practices continued until 1980 when the U. S. Court of Appeals stated the Urban School District and State of Missouri were continuing the cycle of segregation (Grooms, 2016).

In 1983, the St. Louis desegregation program was formed through a settlement agreement which provided students the ability to integrate themselves into St. Louis County schools and, ultimately, other cultures. In 1999, the Voluntary Interdistrict Choice Corporation became the manager of the desegregation program. The hope remained that the members of the community would find integration of schools successful, and therefore be encouraged to join together in creating a more diverse community (Grooms, 2016). Thirty-four years later, the desegregation program in St. Louis continues to exist with the goal of integrating students from the city of St. Louis into schools within St. Louis County.

Background knowledge of the St. Louis community provides a clearer understanding of the continued existence of the desegregation program in St. Louis, as well as the importance of knowing the success or failure rates of student participants. For this study, the researcher will focus on the Voluntary Interdistrict Choice Corporation (VICC) and Suburban School District 
(SSD) as the two organizations of importance. The following sections are designed to provide the reader with additional historical, organizational, and leadership background for VICC and SSD.

\section{History of Organizations}

The Voluntary Interdistrict Choice Corporation (VICC) and Suburban School District (SSD) work in partnership with a goal to provide students with a quality education that offers positive social and academic opportunities in order to promote diversity and close the achievement gap (VICC, 2017). VICC currently serves as the nonprofit organization that manages the St. Louis desegregation program, and SSD is one of 11 St. Louis County school districts participating in the program.

\section{Voluntary Interdistrict Choice Corporation}

The St. Louis Student Transfer program was created in 1983 following a civil settlement

filed by parents who were concerned with the quality of education their children were receiving. After 16 years, the Voluntary Interdistrict Choice Corporation (VICC) took responsibility from the Federal Court and became the manager of the St. Louis desegregation program in 1999 (VICC, 2017). At its peak, the VICC program directed 16 school districts within St. Louis County and enrolled approximately 14,000 students. Currently, VICC manages 11 participating St. Louis County school districts with 4,235 students enrolled. One hundred fifty-seven of these students are St. Louis County residents who have elected to attend magnet schools in the Urban School District (VICC, 2017).

The VICC desegregation program was originally organized with the intent of accepting new students through the 2008-2009 school year. As the end date neared, the VICC Board of Directors approved a 5-year extension for enrollment through the 2013-2014 school year. Again, 
as the 2013-2014 school year approached, the VICC board approved another 5-year extension allowing students to enroll through the 2018-2019 school year. In November 2016, the VICC board finalized their decision and voted to discontinue the VICC desegregation program. The board stated that new students will no longer be able to enroll following the 2023-2024 school year. Between 2018-2024, only siblings of current VICC students will be enrolled. Current students will be allowed to attend participating county school districts through their graduation (VICC, 2017).

\section{Suburban School District}

Suburban School District (SSD) is located in St. Louis County, Missouri, and has a student population of 21,140. The demographic break down shows 78\% Caucasian, 9.1\% African American, 7.1\% Asian, and 3.2\% Hispanic, with $14.7 \%$ of students receiving free or reduced lunch (DESE, 2017). SSD has 30 schools - 19 elementary schools, 6 middle schools, 4 high schools, and 1 alternative high school (RSD, 2017).

SSD maintains a five-year Comprehensive School Improvement Plan (CSIP) through the state of Missouri. This plan has five goal areas of focus: 1) student learning, 2) highly effective staff, 3) district finance, 4) school climate, and 5) governance (RSD, 2017). The CSIP plan provides district students, staff, and parents with the detailed direction for maintaining high levels of student achievement and quality standards among all schools within the organization (RSD, 2017).

By closely following the CSIP plan standards, SSD has a tradition of excellence. Professional staff have an average of 13.8 years of experience and $77.9 \%$ have advanced degrees, which allows for high levels of teaching and learning. In 2016, success of student learning was apparent as $77.2 \%$ of students reported plans to attend a 4-year university, while 
$16 \%$ chose a 2-year institution and $1.2 \%$ chose a technical school (DESE, 2017). Excellence in teaching and learning are areas of importance. However, positive school climate and the wellbeing of students are present in the school community through intentional character education programming and continued encouragement to be involved.

\section{Organizational Analysis}

\section{Voluntary Interdistrict Choice Corporation}

The mission statement for the Voluntary Interdistrict Choice Corporation (VICC) states, "VICC is committed to building relationships, promoting diversity and providing choice while enriching lives through quality educational experiences" (VICC, 2017). These educational experiences are obtained through students from the city of St. Louis attending county school districts, or through students from St. Louis County attending magnet schools in USD.

At its inception in 1983, the St. Louis Transfer Program was managed by the Federal Court system. The management of the desegregation program was transferred to the nonprofit, Voluntary Interdistrict Choice Corporation, in 1999. VICC created an organized structure within the organization, which was essential for its success. According to Bolman \& Deal (2013), the structural framework provides a "blueprint for formally sanctioned expectations and exchanges among internal players and external constituencies" (p. 46).

The VICC program is managed and maintained by the Chief Executive Officer (CEO). Working closely with the CEO are five program administrators who manage various placement aspects, transportation, and applications. There are also VICC coordinators imbedded within each of the 11 participating school districts who act as liaisons for the students and families between the district and VICC. In order to provide additional support, the VICC program employees five counselors that are assigned a student caseload and travel between schools to 
meet with students. Finally, the CEO and a group of area superintendents serve as the governing board for the VICC program (VICC, 2017). The job of the VICC Board of Directors is to oversee the rules, policies, and operating procedures of the program; and make decisions potentially affecting the overall structure of the organization (Bolman \& Deal, 2013).

\section{Suburban School District}

Suburban School District has a complex structural framework that must be maintained to ensure the success of the district. In a district that employees so many, attrition naturally occurs. What could be detrimental to an organization has little effect on SSD. Through consistent processes, procedures, and progressive discussions, students continue to thrive academically, socially, and emotionally.

Similar to the VICC program, SSD has a basic vertical coordination within the organization (Bolman \& Deal, 2013). However, it has a lot of moving parts that are essential for success of the organization. The Board of Education, consisting of elected community members, is above all and works alongside the Superintendent to make decisions that govern the policies and procedures of the district. The Superintendent is the leader of the school district. He manages all aspects of the district with the support of three Assistant Superintendents. Executive directors, directors, and coordinators for curriculum, technology, student support services, and communications are supervised and report to their respective Assistant Superintendents. Assistant Superintendents and executive directors provide direct supervision for building principals. Within the schools, the principal supervises the assistant principals, teachers, staff, and students (RSD, 2017).

Although district administrators have authority in planning programs in the school district, school administrators have the autonomy to implement programs within their individual 
schools (Bolman \& Deal, 2013). With 23 district schools, the needs of the students, staff, parents, and community members vary greatly. Bolman \& Deal (2013) state, "People and organizations need each other...A good fit benefits both. Individuals find meaningful and satisfying work, and organizations get the talent and energy they need to succeed" (p. 117)

\section{Leadership Analysis}

\section{Voluntary Interdistrict Choice Corporation}

The leadership structure of the Voluntary Interdistrict Choice Corporation is multifaceted and works in partnership with participating school districts. The current Chief Executive Officer has been in leadership with the organization for 6 years, and provides consistency to the program. He is a strong advocate for his students, and provides resources to students and families for academic success. Each school district participating in the VICC program has a coordinator who serves as a liaison between the district schools and VICC CEO.

VICC coordinators work closely with families and students to provide support that school districts may not be able to provide, such as homeless and homebound services, financial assistance with housing, dental and vision appointments with transportation, and student involvement in community events. VICC coordinators collaborate with school administrators to troubleshoot behavioral issues, student needs, and academic concerns. They schedule regular onsite visits with students to discuss their progress and plans for the future. The VICC coordinator for SSD also provides therapeutic services to African American students in the form of groups. These groups consist of fewer than 12 students who meet weekly with a representative from an outside agency. This individual teaches tolerance, acceptance, understanding, and selfesteem/self-respect.

VICC also provides counseling services to students and families. Counseling services are provided by social workers that are employed by VICC and meet with students in their homes or 
at school on a consistent basis. This service is free of charge and is an excellent supplement to counseling or therapeutic programs that the student is currently accessing at school.

A major component of the VICC program is transportation. VICC has a transportation manager, routers, safety supervisors, and monitors that work with each school district to provide taxicab and bus services for the students. As VICC outsources their transportations services, the VICC transportation manager must act as a liaison between the bus company, schools, and families. Although the transportation manager is not consistently in district buildings, it is important for her to keep a pulse on the needs of students and adults. Timeliness of bus arrival and departure is necessary; along with communication of behavioral issues, 504/IEP student issues, homeless status, and address changes.

\section{Suburban School District}

Suburban School District (SSD) has a history of consistency and longevity of district and school leadership. As students within the district excel academically, SSD is often viewed as an attractive place to work. Gaining employment in the district is often difficult, as applicant numbers are high for relatively few vacant positions.

The current superintendent for SSD has been in his role for 4 years. During this time, he has focused on the understanding and implementation of the district Comprehensive School Improvement Plan (CSIP). The CSIP has five goal areas of focus: 1) student learning, 2) highly effective staff, 3) district finance, 4) school climate, and 5) governance (RSD, 2017). SSD has received recognition for excellence in all categories. The superintendent continues to focus on these goal areas with district and school leaders. Communication is another area of importance to the superintendent. He values communication, and makes a point to visit all 23 district schools at least 3 times per school year. During his visits, he enters every classroom in the building and 
engages with the students and teachers. He has built a strong rapport with students, teachers, parents, and members of the community.

The mission statement for SSD states, "We do whatever it takes to ensure all students realize their potential" (RSD, 2017). This is especially true in the individual buildings across the district. School administrators collaborate as a Professional Learning Community (PLC) on a regular basis to evaluate processes and procedures in their buildings, and check for progress on building and district goals. They also collaborate with teachers, counselors, and parents for the success and well-being of students. SSD staff members focus on the needs of the individual child and plan programs accordingly.

SSD schools have varying programs in place to monitor student progress, such as: Response-to-Intervention (RTI) teams, problem solving teams, boys' and girls' groups, counseling sessions, Youth-In-Need (YIN) counseling services, and after school tutoring. Although these services exist, building leadership teams are finding creative solutions to engage students in their learning through project-based learning opportunities and lessons involving innovative thinking.

\section{Implication for Research}

The VICC desegregation program will close enrollment as of the 2023-2024 school year, allowing already enrolled students to continue attending St. Louis County high schools through graduation. With the discontinuation of the program, participating school districts will see a natural decline in enrollment and diversity in their schools. Similarly, students in the city of St. Louis will no longer be afforded the opportunity to participate in diverse programs, and the attendance of schools in Urban School District will increase. 
Currently, there is little literature defining the social and academic impact of the VICC desegregation program on student success. The hope for this study is to discover whether or not VICC students are finding their educational experiences to be positive. The researcher will focus on the social and academic impact of students by analyzing attendance rates, graduation rates, dropout rates, ACT scores, and EOC scores. If a significant result is found showing positive results, the results will be shared with the SSD superintendent, the CEO of the VICC desegregation program, participating county school districts, and the education community. There could be an argument for the continuation of the VICC program or the possibility of providing students with a similar experience.

If a significant result is not discovered, the researcher will share the results with stakeholders of the VICC program. There could be a suggestion to look for other methods to provide experiences of diversity for students while educating students in their assigned neighborhood schools.

\section{Summary}

The Voluntary Interdistrict Choice Corporation (VICC) and Suburban School District (SSD) work as a partnership to provide students from the city of St. Louis with the opportunity to access differing resources, backgrounds, and experiences than their assigned district schools. For this partnership to be successful, strong organizational systems must be in place.

VICC and SSD share similar structural frameworks that define a vertical process of leadership. Each organization has a leader in charge of managing the processes and procedures within. However, leadership is a shared responsibility among all members of the community, with the goal of providing students with a solid educational experience. 
With the knowledge that the VICC program will no longer accept new applications as of the 2023-2024 school year, the researcher will analyze social and academic impact data to further understand any successes or failures of the program. As results are discovered, they will be shared with members of the education community. The hope for this research is to discover whether or not students enrolled in the VICC program are benefitting from their experiences. After 34 years of students being integrated, the VICC program is ending. Why? After two 5-year extensions, why end the program now? 


\section{CHAPTER THREE:}

SCHOLARLY REVIEW FOR THE STUDY 


\section{Introduction}

Separate but equal. When these three words became law in the 1896 Supreme Court case, Plessy v. Ferguson, permission was granted for African American citizens and white citizens to be divided... separated... segregated. Although stated as a requirement in the determination of the Supreme Court, equality was not present in all areas of society. Public facilities did not reflect the same conveniences. Resources were not distributed equally, especially in the educational system. Eventually, activists began discussing the inequalities and gap in achievement among African American and white students, which led to the 1954 Supreme Court case, Brown v. Board of Education of Topeka. This case stated that "separate but equal" was not just, and determined that white and African American students should be integrated (Epps-Robertson, 2016). In the years following, desegregation programs such as the Voluntary Interdistrict Choice Corporation (VICC) in St. Louis, Missouri, were created in an effort to integrate schools and communities and close the achievement gap.

When selecting an area for research, Colquitt \& George (2011) suggest choosing a topic that would be considered a "grand challenge," one that could potentially create a change in education. During my tenure as an administrator, I have come to realize how few people truly understand the importance of the VICC program and its impact on the students enrolled. Negative focus on non-academic areas often occurs and overshadows the positive aspects of the program. Organizing transportation and extracurricular activities to include VICC students can be a complicated, logistical nightmare, as transportation is often unreliable. African American students in the program traditionally have more disciplinary issues than non-VICC county students. These issues and more often minimize the benefits for the students involved. Reber (2010) states that students attending schools focused on desegregation plans provide students 
with a quality education ultimately resulting in decreased drop-out rates, increased involvement, and increased student achievement.

Since interacting with the VICC program, I can honestly say that I have never analyzed the achievement data of students enrolled. Therefore, I have decided to focus my research on this topic to further understand the difference in student achievement of African American students enrolled in the Voluntary Interdistrict Choice Corporation in St. Louis and attending county schools compared to students enrolled in the Urban School District as measured by dropout rates, graduation rates, attendance rates, end-of-course exams, and ACT scores. In order to gain a deeper understanding of the VICC program, the following literature review will focus on the purpose of desegregation of school districts and on the achievement gap between African American and white students.

\section{Desegregation}

The historical impact of desegregation has been present in education for over 100 years. Although short in stature, the phrase, "separate but equal," created significant practices of segregation, which divided the citizens into two main factions - white or African American. The phrase "separate but equal" was first stated in the judgement of the 1896 Supreme Court case, Plessy v. Ferguson. The Supreme Court upheld the previously written Jim Crow laws, ruling that it was acceptable to require white and African American citizens to use separate facilities, as long as all citizens were provided access to equal resources and opportunities. Unfortunately, not all facilities were presented with comparable resources or ease of location (Hoffer, 2014).

In 1951, Linda Brown, an African American elementary student, had to walk through a railroad switchyard each morning to get to her bus stop. On her route, Brown traveled past an allwhite elementary school. Brown's parents petitioned the court to allow for their daughter to 
attend the all-white school near their home. In Brown, the Brown's challenged that their daughter did not have equal access to education due to the location of her school and required travel time (Landmark Cases, 2017). The defendants also presented information suggesting that school resources in African American schools were inferior when compared to white schools. Wasserman, Connelly, \& Steen (2015) state, "it was alleged that white schools had one teacher for every twenty-eight pupils, while black schools had one teacher for every forty-seven students; white schools were brick and stucco, while black schools were made of wood; white schools had indoor plumbing, while black schools had outhouses" (p. 1). In 1954, Supreme Court Justice, Earl Warren, stated, "We conclude that, in the field of public education, the doctrine of 'separate but equal' has no place. Separate educational facilities are inherently unequal' (Lawrence, 2012). This determination ended a 58-year-old precedent from Plessy v. Ferguson, stating that it was lawful to separate races in public areas, such as schools, as long as individuals had access to the same resources (Birzer \& Ellis, 2006).

Following the Brown decision, districts began slowly integrating schools to reflect multiple ethnicities within the student population (Miyasaki, 2015). However, opposition to fully integrate schools continued for many years following the Brown decision. In Arkansas, strong feelings of both acceptance and opposition of Brown were felt across the state. Districts enrolling smaller populations of African American students were among the first to integrate due to financial considerations (Kirk, 2011). These districts found that bussing African American students to designated schools in or out of their districts was creating an increased per pupil expenditure. One such district in Arkansas was bussing African American students nearly 27 miles from home to a school of color. Allowing students to attend schools near their homes created a savings of approximately $\$ 5,000$ in transportation costs per year. In an interview about 
the integration of the Fayetteville system, Wayne White, superintendent of schools, told reporters that "segregation was a luxury we could no longer afford" (Kirk, 2011). However, larger districts in Arkansas struggled with the concept of school desegregation. Several districts created integration plans detailing a multi-year process before African American and white students would be learning together. In several districts, school officials voted to dismiss the idea of integration altogether (Kirk, 2011).

In Little Rock, Arkansas, the North Little Rock School District avoided school desegregation for several years following the Brown decision (Cope, 2015). The superintendent of schools originally stated that integration would not be an issue as no African American students lived in the proper attendance zones to attend district schools. In addition, community members were opposed to African American students attending schools within the district, and created a petition obtaining approximately $80 \%$ of the community's signatures in support of maintaining all-white schools.

After a year, North Little Rock High School was directed by government officials to integrate. School administrators created a two-year plan in which to bring 23 African American students into the high school setting. Near the end of the two-year time frame, students were still not integrated. Instead, African American students were instructed to be taken to nearby Scipio Jones High School and told that integration was to be "shelved indefinitely" (Cope, 2015). Six days later, six African American students entered North Little Rock High School along with prominent members of the African American community, and demanded a meeting with the school board. Ultimately, the students were told that, due to overcrowding, space did not exist in the building and they were directed back to Scipio Jones High School, where they remained through graduation (Cope, 2015). 
In Prince Edward County, Virginia, state officials strongly opposed desegregation of their schools and created legislation to halt requirements of Brown. This idea of opposition became known as Massive Resistance (Epps-Robertson, 2016). Senator Harry F. Byrd argued, “This reversal by the Supreme Court from its 'separate but equal' policy to complete abolition of segregation will create problems such as have never confronted us before" (Epps-Robertson, 2016, p. 112). Rather than develop a plan to integrate the schools in Prince Edward County, community members closed the public school system and created the private, all-white Prince Edward Academy. In an effort to create equality, school officials offered to aid in the creation of an African American private school, which was never entertained. Therefore, children in the African American community were denied an education for five years perpetuating the achievement gap (Epps-Robertson, 2016).

Stories of segregation were commonplace and several equity-based complaints were filed with the court system during the years following the Brown decision, causing new policies to be written and others rewritten before desegregation efforts occurred throughout the nation (Diem \& Brooks, 2013). One of the most important moments in the civil rights movement was the passage of the Civil Rights Act on June 2, 1964, which outlawed racial discrimination and banned prejudice. It stated the following:

All persons shall be entitled to the full and equal enjoyment of the goods, services, facilities, and privileges, advantages, and accommodations of any place of public accommodation, as defined in this section, without discrimination or segregation on the ground of race, color, religion, or national origin (Karatzas, 2016, p. 31).

Although the Civil Rights Act of 1964 eventually ended segregation practices in schools, political leaders quickly began to realize that neighborhoods were not integrated. Therefore, 
student populations remained the same as they were before the passage of the bill. Rothstein (2015) states, "Education policy is constrained by housing policy: it is not possible to desegregate schools without desegregating both low-income and affluent neighborhoods (p. 21). In discussions of potential solutions, political leaders realized that bussing students was a viable option as it was successful in previous years during times of mandated segregation (Graglia, 2014).

In 1972, a group of parents from St. Louis, Missouri, filed a class action lawsuit stating that students in the city were not receiving the same level of education as students in St. Louis County (Grooms, 2016). In 1980, the U. S. Court of Appeals upheld the lawsuit declaring that both the State of Missouri and the St. Louis Public School district board of education were accountable for perpetuating a segregated school system. In 1983, a settlement agreement was created allowing for African American students residing in the City of St. Louis to attend participating schools within St. Louis County, and allowing white students in St. Louis County to attend magnet schools in the city of St. Louis (Grooms, 2016). The State of Missouri agreed to cover the cost of the program and transportation; and indicated a goal of the state to attain a population of at least $25 \%$ African American students in attendance in county schools.

In 1999, the non-profit, Voluntary Interdistrict Choice Corporation (VICC), was recognized as the manager of the desegregation program through the intended end of the program in the 2008-2009 school year. Through two separate votes by the VICC board of directors, the VICC desegregation program was granted extension and continued well past the 2008-2009 school year. Unfortunately, the participation of school districts in St. Louis County decreased from 16 districts to 11 districts, and the number of students enrolled fell from its peak enrollment of 14,000 students to approximately 5,000 students (VICC, 2017). In 2017, the Board 
of Directors for the VICC program announced that they would no longer accept new students as of the 2023-2024 school year. Students already enrolled in the program and attending a participating county school would be able to continue through their graduation years (VICC, 2017).

When established in 1983, the goal of the VICC program was to promote desegregation in St. Louis County schools and the St. Louis Public School district, while encouraging movement of families in the community to locations outside of the St. Louis city. After 35 years, segregation continues to exist in the St. Louis city and St. Louis County areas, and the VICC Board of Directors have concluded that the program has not been effective in achieving it's intended purpose of encouraging members of the community to move their families and blend together in an integrated society (VICC, 2017). As the VICC program comes to a close, educators will be watching the effects on the students as they are reintroduced to a more segregated school system and community.

\section{Achievement Gap}

Historical practices in both education and society have perpetuated an achievement gap between white and African American students. Although integration has been present in our society for approximately sixty years, the achievement gap between white students and African American students remains. Research indicates a variety of reasons for the existence of the achievement gap. According to Harackiewicz, et. al. (2015), “these achievement gaps can be attributed to a number of economic and social factors such as poverty, quality of schools, economic resources, and academic preparation" (p. 745).

During times of segregation, African American families often lived in areas of low income housing and high poverty, and did not have access to the same resources as the majority 
of white families. African American students often traveled far distances to reach their designated schools, and frequently were absent due to responsibilities at home or illness due to poor health benefits (Rothstein, 2015). Unfortunately, the majority of African American families that once lived in poverty continue to do so today. Rothstein (2015) suggests that students living in such conditions for multiple generations add an additional barrier to achievement due to their familial experiences, absence of enrichment opportunities, greater illiteracy among parents, and lack of resources. Additionally, the mobility of African Americans must be taken into account, as families often move from one house to another, but remained in areas of poverty (McDonough, 2015). When segregation exists in areas of disadvantaged children, the achievement gap is perpetuated as these groups of children will be attending schools within the same district (Downey \& Kondron, 2016).

Kotok (2017) states that the "achievement gap persists because minority students are more likely to enter high school without the necessary skills" (p. 183). Educators must begin the school year with remediation lessons, which does not allow high achieving students to be challenged. Due to student mobility, teachers also spend invaluable time re-teaching lessons to a large numbers of new students entering the schools, which then takes time away from creating lessons to reach all levels of learners. Educators often have to focus more attention on behavior of students, as they may act out in response to not understanding the curriculum being taught (Rothstein, 2015).

When reflecting on the judgement made by the Supreme Court in the case of Brown v. Board of Education of Topeka, Palardy, Rumberger, \& Butler (2015) state that the "decision was not based solely upon the notion that segregated black schools were inferior in terms of academic instruction, curricular rigor, resources, etc., but also on research that showed segregating black 
children had negative social-emotional and behavioral consequences" (p. 1). Rothstein (2016) states that low-income neighborhoods are often surrounded by violence and crime, which creates stress for students and decreases learning. Jones \& Schindler (2015) suggest that a strong school climate has a positive effect on student achievement. Solid connections to quality teachers reduces stress by building relationships and trust, which leads to higher student achievement. Research indicates that quality teachers are unequally distributed. Strong teachers are moving to districts with more resources and better compensation (Downey \& Condron, 2016).

The end of segregation through Brown and the continued presence of the achievement gap has led to the creation of alternative educational programs focused on student achievement, such as: desegregation programs, magnet schools, and charter schools (McCarthy, 2015). These programs were created throughout the United States in areas of segregation and poverty. In 1980, the desegregation program in St. Louis, Missouri, was established to integrate educational facilities and the larger community. African American students in the City of St. Louis could apply to attend participating school districts within the predominately white St. Louis County. In turn, students residing in St. Louis County could attend magnet or charter schools within the City of St. Louis. While integration was the main component of the desegregation program, a large focus of the program was providing African American and white students with equitable resources and experiences to assist in closing the achievement gap (VICC, 2017). However, the creation of alternative education programs did not always have the desired effect on student achievement. Gamoran \& An (2016) state the following regarding magnet schools:

As the academically selective magnet schools are becoming more White, and the nonselective magnets are increasingly Black, one may speculate that magnet schools may contribute to wider achievement gaps - not because of the effects of magnet schools per 
se, but because they constitute a form of between-school tracking which, because Whites tend to be over-enrolled and Blacks under-enrolled in the most selective locations, magnifies the overall achievement gap (p. 47).

In a recent study, O'Malley, Roseboro, and Hunt (2012) discuss the achievement of students in the East St. Louis school district. According to the authors, the achievement of the school district began falling due to white students and strong teachers leaving the district to attend area magnet schools. State funding soon decreased, as did the achievement of the students remaining in the district. Researchers found that as the district became financially stable years later, the achievement of the students in the district did not increase. Truancy, drop-out rates, and graduation rates continued to suffer, as stronger students and teachers remained in surrounding districts. Peterson, et. al. (2016) suggest that teacher expectations are imperative to the academic success of students. When teachers provide students with high-level opportunities in a fair and supportive environment, students of all genders and ethnicities will respond with higher levels of learning.

Chu (2011) said, "The racial achievement gap reflects the inequality in educational experience" (p.202). State and federal programs, such as No Child Left Behind (NCLB) and Race to the Top (RTTT), were created in an effort to bring the achievement gap in focus and designed standards to target the learning of all students (Kotok, 2017). Unfortunately, these standards created a focus on student test results, which put a strain on educators and often changed the direction of curriculum writing to meet the needs of the test instead of the needs of the student. Focus on testing also created an increase in the per pupil expenditure paid for by the school district for participation in more standardized testing. Dee, Jacob, \& Schwartz (2013) state, "The federal government brought test-based accountability to scale with the 
implementation of the No Child Left Behind Act (NCLB) during the 2002-2003 school year. NCLB required both annual student testing and school-level reporting that indicated whether schools were succeeding or failing to make "adequate yearly progress" (AYP) toward proficiency goals" (p. 253).

Kim, Turner, \& Yazdian (2014) agree that teachers have lost the ability to use their innovative teaching techniques in the classroom, as educators often feel that they must teach to the test. For students entering high school with gaps in their knowledge, this method of teaching has been detrimental. Instead of beginning with remediation, students are often moved through a quickly paced curriculum in order to be introduced to all concepts that should appear on the standardized tests at the end of the school year. Kim, Turner, \& Yazdian (2014) state that "educational reforms intend to make changes in the way students learn, but often miss the mark by focusing on tasks that do not bring real educational benefits to students and teachers" (p. 173). Although NCLB and RTTT created an intentional focus on teaching and learning, the achievement gap continues to exist.

Unintentional segregation continues to exist in many areas of our country, and the achievement gap continues to plague our students (McCarthy, 2015). While many schools have diverse populations, they continue to face the difficult challenge of learning, understanding, and implementing components of desegregation. Educators have to be willing to develop curriculum that maintains respectful acceptance among students while providing a solid and inclusive learning environment that will help to close the achievement gap (Welton, 2013). School districts must concentrate on hiring quality teachers and reallocating funds in order to provide students with exceptional resources to meet their learning needs. 


\section{Conclusion}

Logan (2016) states, "high school segregation persists in the United States despite attempts to desegregate schools" (p. 324). Inequity continues to plague our education system, which perpetuates the achievement gap and need of families to look for alternate educational placements outside of their neighborhood schools. After six decades of focusing on desegregation in our schools, African American students are still searching for a better educational opportunity. In many cases, students are leaving their home schools in impoverished neighborhoods to attend those in predominantly white suburbia, knowing the potential presence of more funding and better resources for a quality education (Welton, 2013). Desegregation programs, such as the Voluntary Interdistrict Choice Corporation, provide students the opportunity to a free, public education in any one of the participating school districts in St. Louis County in an effort to increase diverse populations and close the achievement gap (VICC, 2016).

Welton (2013) states that desegregation programs are a benefit to all students involved. Students learn diversity, cultural characteristics of others, acceptance, and tolerance. Desegregation and the achievement gap are both areas of focus for the staff and students, and inclusivity is a priority in order to provide a positive educational opportunity for all. The challenge that diverse schools face is continuing the learning and understanding of desegregation in order to maintain respectful acceptance among students in order to provide a solid and inclusive learning environment that will help to close the achievement gap (Welton, 2013). 


\section{References}

Chu, S. (2011). Perspectives in understanding the schooling and achievement of students from culturally and linguistically diverse backgrounds. Journal of Instructional Psychology, 38(3/4), 201-209.

Cope, G. (2015). "Something would develop to prevent it": North Little Rock and school desegregation, 1954-1957. Arkansas Historical Quarterly, 74(2), 109-129.

Diem, S. \& Brooks, J. (2013). Introduction to the issue on segregation, desegregation, and integration: from history, to policy, to practice. Teachers College Record, 115(11).

Downey, D. B., \& Condron, D. J. (2016). Fifty years since the Coleman report: Rethinking the relationship between schools and inequality. Sociology of Education, 89(3), 207-220. doi:10.1177/0038040716651676

Frankenberg, E., Diem, S., \& Cleary, C. (2016). School desegregation after parents involved: The complications of pursuing diversity in a high-stakes accountability era. Journal Of Urban Affairs, doi:10.1111/juaf.12309

Gamoran, A. \& An, B. (2016). Effects of school segregation and school resources in a changing policy context. Educational Evaluation and Policy Analysis, 38(1), 43-64. doi:10.3102/0162373715585604

Graglia, L. A. (2014). The Supreme Court's perversion of the 1964 Civil Rights Act. Harvard Journal of Law \& Public Policy, 37(1), 103.

Grooms, A. A. (2016). Money or diversity? An implementation analysis of the Voluntary Transfer Program in St. Louis, 1999-2009. Education Policy Analysis Archives, 24(20). 
Harackiewicz, J. M., Canning, E. A., Tibbetts, Y., Priniski, S. J., \& Hyde, J. S. (2016). Closing achievement gaps with a utility-value intervention: Disentangling race and social class. Journal of Personality \& Social Psychology, 111(5), 745-765. doi:10.1037/pspp0000075

Jones, A. \& Shindler, J. (2016). Exploring the school climate--student achievement connection: Making sense of why the first precedes the second. Educational Leadership and Administration: Teaching and Program Development, 27, 35-51.

Karatzas Konstantinos, D. (2016). Lyndon B. Johnson and the Civil Right Act of 1964. Vestnik Volgogradskogo Gosudarstvennogo Universiteta. Seriâ 4. Istoriâ, Regionovedenie, Meždunarodnye Otnošeniâ, 21(3), 25-33. doi:10.15688/jvolsu4.2016.3.3

Kim, Y., Turner, J., \& Yazdian, L. (2014). Special issue: Looking back and moving forward: No Child Left Behind, Race to the Top, and Quality Teaching. Theory into Practice, 53(3), 173-175.

Kirk, J. (n.d). Not quite black and white: school desegregation in Arkansas, 19541966. Arkansas Historical Quarterly, 70(3), 225-257.

Landmark Cases (2017). As retrieved from http://landmarkcases.org/en/landmark/cases/ brown_v_board_of_education\#Tab=Overview

Lawrence, A. (2012). Herbert Brownell, Jr.: The 'hidden hand' in the selection of Earl Warren and the government's role in Brown v. Board of Education. Journal of Supreme Court History, 37(1), 75-92. doi:10.1111/j.1540-5818.2012.01283.x

Logan, J. R. \& Burdick-Will, J. (2016). School segregation, charter schools, and access to quality education. Journal of Urban Affairs, 38(3), 323-345. doi: 10.1111/juaf.12246 
Martin, M. M., \& Ngcobo, J. N. (2015). Social justice as a conduit for broadening curriculum access: Stories from classroom teachers. Perspectives in Education, 33(1), 87-99.

McCarthy, K. D. (2015). The battle of the branches: The impact of the judiciary and Title VI on desegregation in the American public school system. San Diego Law Review, 52(4), 967980.

McDonough, I. K. (2015). Dynamics of the black-white gap in academic achievement. Economics of Education Review, 4717-33. doi:10.1016/j.econedurev.2015.03.007

Missouri Department of Elementary and Secondary Education (2017). Retrieved from https://dese.mo.gov

Miyasaki, R. (2015). Asleep at the school-bus wheel: The success and failure of school desegregation in San Jose United School District and how to save it. Golden Gate University Law Review, 45(2), 149-172.

O’Malley, M. P., Roseboro, D. L., \& Hunt, J. (2012). Accountability, fiscal management, and student achievement in East St. Louis, Illinois 1994-2006: Implications for urban educational reform policy. Urban Education, 47(1) 117-143. doi:

$10.1177 / 0042085911427741$

Palardy, G. J., Rumberger, R. W., \& Butler, T. (2015). The effect of high school socioeconomic, racial, and linguistic segregation on academic performance and school behaviors. Teachers College Record, 117(12).

Parsons, E. R., \& Turner, K. (2014). The importance of history in the racial inequality and racial inequity in education: New Orleans as a case example. Negro Educational Review, 65(1-4), 99-113. 
Peterson, E., Rubie-Davies, C., Osborne, D., \& Sibley, C. (2016). Teachers' explicit expectations and implicit prejudiced attitudes to educational achievement: Relations with student achievement and the ethnic achievement gap. Learning and Instruction, 42, 123-140. doi:10.1016/j.learninstruc.2016.01.010

Reber, S. J. (2010). School desegregation and educational attainment for blacks. Journal of Human Resources, 45(4), 893-914.

Rockwood School District (2017). Retrieved from www.rsdmo.org

Rothstein, R. (2015). The racial achievement gap, segregated schools, and segregated neighborhoods: A constitutional insult. Race and Social Problems, 7(1), 21-30. doi:10.1007/s12552-014-9134-1

St. Louis Public Schools (2017). Retrieved from https://www.slps.org/domain/5110 Thomas, D., Jacob, B., \& Lee, N. (2013). The effects of NCLB on school resources and practices. Educational Evaluation and Policy Analysis, (2), 252.

Voluntary Interdistrict Choice Corporation (2017). Retrieved from http://www.choicecorp.org Wasserman, L. M., Connolly, J. P., \& Steen, P. L. (2015). United States Supreme Court Justices' voting in systemic racial discrimination cases in education. Urban Lawyer, 47(1), 1.

Welton, A. (2013). Even more racially isolated than before: Problematizing the vision for "diversity" in a racially mixed high school. Teachers College Record, 115(11), 1-42. 
CHAPTER FOUR:

CONTRIBUTION TO PRACTICE 
Program Evaluation for the Voluntary Interdistrict Choice Corporation

\section{Table of Contents}

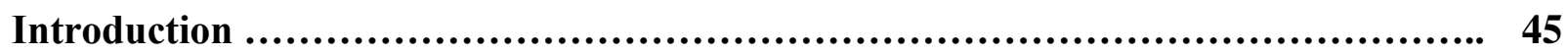

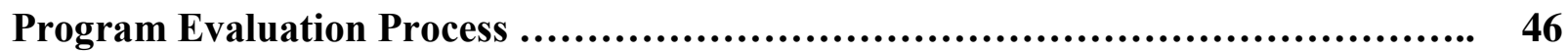

Research Questions and Hypotheses ...................................... 48

Current Definition of the VICC Program ...................................... 49

Current Status of the VICC Program ....................................... 50

Strengths and Concerns for the VICC Program .................................... 51

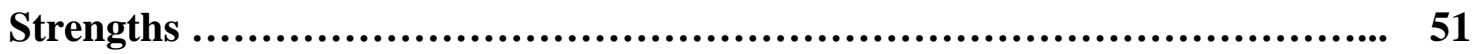

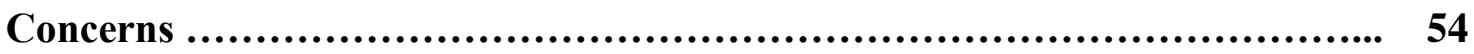

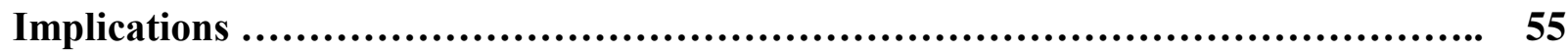

Researcher Recommendations ..................................................... 56

Recommendations for Leadership ...................................... 57

Recommendations for Program Implementation and Education ................ 57

Recommendations for Program Monitoring ................................. 59

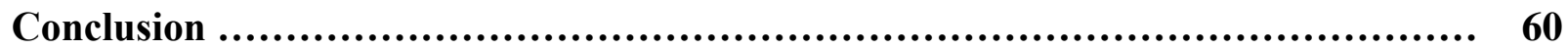

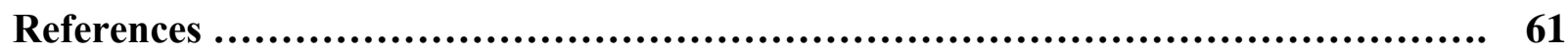


University of Missouri-Columbia

Voluntary Interdistrict Choice Corporation

Spring 2018

\begin{tabular}{|c|c|c|}
\hline Researcher & District & Position \\
\hline Amanda M. Lewis & Rockwood School District & Administrator \\
& University of Missouri & Doctoral Candidate \\
\hline Research Advisor & & \\
\hline Dr. Paul Watkins & $\begin{array}{c}\text { Southeast Missouri State } \\
\text { University }\end{array}$ & Faculty \\
\hline
\end{tabular}




\section{Introduction}

In 1954, Supreme Court Justice, Earl Warren, penned the court's decision in the case of Brown v. the Board of Education of Topeka. He wrote, "We conclude that, in the field of public education, the doctrine of 'separate but equal' has no place. Separate educational facilities are inherently unequal" (Lawrence, 2012). Following Brown, desegregation did not begin automatically or easily. There were many forms of descent including various legal battles, direct disobedience, subversion, and demonstrations. Stories of segregation were commonplace and several equity-based complaints were filed with the court system during the years following the Brown decision. New policies were written and others rewritten before desegregation efforts occurred throughout the nation (Diem \& Brooks, 2013).

One of the most important moments in the civil rights movement was the passage of the Civil Rights Act on June 2, 1964, which outlawed racial discrimination and banned prejudice. It stated the following:

All persons shall be entitled to the full and equal enjoyment of the goods, services, facilities, and privileges, advantages, and accommodations of any place of public accommodation, as defined in this section, without discrimination or segregation on the ground of race, color, religion, or national origin (Karatzas Konstantinos, 2016, p. 31). Although the Civil Rights Act of 1964 eventually ended segregation practices in schools, political leaders quickly began to realize that segregated neighborhoods preserved the lack of integration in student populations. Rothstein (2015) states, "Education policy is constrained by housing policy: it is not possible to desegregate schools without desegregating both low-income and affluent neighborhoods (p. 21). In discussions of potential solutions, political leaders realized that bussing students was a viable option as it was successful in previous years during times of mandated segregation (Graglia, 2014). 
In 1972, a group of parents from St. Louis, Missouri, filed a class action lawsuit stating that students in the city were not receiving the same level of education as students in St. Louis County (Grooms, 2016). In 1980, the U. S. Court of Appeals upheld the lawsuit declaring that both the State of Missouri and the Urban School District Board of Education were accountable for perpetuating a segregated school system. In 1983, a settlement agreement was created allowing for African American students residing in the city of St. Louis to attend participating schools within St. Louis County, while concurrently allowing white students in St. Louis County to attend magnet schools in the city of St. Louis (Grooms, 2016). The State of Missouri agreed to cover the cost of the program and transportation; and indicated a state goal to attain a population of at least $25 \%$ African American students in attendance in county schools.

In 1999, the non-profit, Voluntary Interdistrict Choice Corporation (VICC), took over the management of the program with the intention of closing enrollment within 10 years. In November 2016, the Board of Directors for the VICC desegregation program in St. Louis, voted to end enrollment in the program as of the 2023-2024 school year. Between 2018-2024, a minimal amount of siblings of current VICC students would be considered. For the 2018-2019 school year, VICC will accept 250 students. By 2023-2024, only 125 students will be enrolled. Once all students have successfully graduated, the VICC program will officially end.

As our nation approaches nearly 65 years of integration in education, an achievement gap continues to exist. Why? If all students are able to access the same level of education and resources for learning, shouldn't students be learning at the same rate?

\section{Program Evaluation Process}

The researcher completed a quantitative study designed to compare the social and academic impact data of two core groups of students. They are: 1) students in grades 9-12 within 
the city of St. Louis, Missouri, enrolled in the Urban School District (USD), and 2) African American students in grades 9-12 from the city of St. Louis, enrolled in the VICC desegregation program and attending schools in Suburban School District (SSD) in St. Louis County. African American students in the Suburban School District were separated to create a subset of students including only participants in the Voluntary Interdistrict Choice Corporation from all four high schools. The comparison group of Urban School District students included the entire population of students from the three traditional public high schools in the district. The participant populations from each school and year can be found in Table 1. The four Suburban high schools used for the study are coded as: SSD1, SSD2, SSD3, and SSD4. The total SSD population for all four high schools is also listed in Table 1. Urban School District high schools are displayed as: USD1, USD2, and USD3. The total USD population for each school year is also recorded in Table 1.

Table 1

Population of SSD and USD High Schools per School Year of Study

\begin{tabular}{lrrrrrrrrr}
\hline School Year & SSD 1 & SSD 2 & SSD 3 & SSD 4 & SSD Total & USD 1 & USD 2 & USD 3 & USD Total \\
\hline $2014-2015$ & 206 & 464 & 300 & 216 & 1186 & 625 & 440 & 645 & 1710 \\
$2015-2016$ & 198 & 255 & 414 & 190 & 1057 & 518 & 356 & 616 & 1490 \\
$2016-2017$ & 173 & 220 & 331 & 157 & 881 & 462 & 320 & 510 & 1292 \\
\hline
\end{tabular}

This study reviewed longitudinal data for three consecutive school years: 2014-2015, 2015-2016, and 2016-2017. The researcher utilized DESE to access school and district report card data for attendance rates, graduation rates, drop-out rates, ACT scores and EOC scores for students in USD. The same data for VICC students enrolled in SSD was obtained from the district data department. This information needed to be further analyzed in order to separate data for African American students enrolled in the VICC program from non-VICC African American students residing in St. Louis County. 
Student enrollment numbers for the three focus years of the study were evaluated using descriptive statistics, and are displayed in Table 1. Social and academic impact data was analyzed using the IBM software program, Statistical Package for the Social Sciences (SPSS). The researcher utilized the one-way ANOVA feature of SPSS to compare means of the independent variables to determine an existence of statistical significance in the data. ANOVA output for each data set was placed in tabular format to expedite analysis of the data.

\section{Research Questions and Hypotheses}

There are five main research questions guiding this study, with each question focusing on specific social and academic impact data. The questions and hypotheses are as follows:

Q1: What is the difference in the attendance rates of African American students in grades 912 enrolled in the Voluntary Interdistrict Choice Corporation desegregation program, as compared to students in grades 9-12 enrolled in the Urban School District?

H1: It is predicted that the attendance rates will show a positive statistical significance for VICC students attending Suburban School District (SSD) high schools.

Q2: What is the difference in the graduation rates of African American students in grades 912 enrolled in the Voluntary Interdistrict Choice Corporation desegregation program, as compared to students in grades 9-12 enrolled in the Urban School District?

$\mathrm{H} 2$ : It is predicted that the graduation rates will show a positive statistical significance for VICC students attending Suburban School District high schools.

Q3: What is the difference in the drop-out rates of African American students in grades 9-12 enrolled in the Voluntary Interdistrict Choice Corporation desegregation program, as compared to students in grades 9-12 enrolled in the Urban School District?

H3: It is predicted that the drop-out rates will show a positive statistical significance for 
VICC students attending Suburban School District high schools.

Q4: What is the difference in the ACT scores of African American students in grades 9-12 enrolled in the Voluntary Interdistrict Choice Corporation desegregation program, as compared to students in grades 9-12 enrolled in the Urban School District?

H4: It is predicted that the ACT scores will show a positive statistical significance for VICC students attending Suburban School District high schools.

Q5: What is the difference in the End-of-Course (EOC) exam scores of African American students in grades 9-12 enrolled in the Voluntary Interdistrict Choice Corporation desegregation program, as compared to students in grades 9-12 enrolled in the Urban School District?

H5: It is predicted that the EOC scores will show a positive statistical significance for VICC students attending Suburban School District high schools.

\section{Current Definition of the VICC Program}

Desegregation efforts for St. Louis students existed for years following the 1983 settlement agreement which began the transfer program. In 1999, the non-profit, Voluntary Interdistrict Choice Corporation (VICC), was recognized as the manager of the desegregation program through its intended end in the 2008-2009 school year. Through two separate votes by the VICC Board of Directors, the VICC desegregation program was granted extension and continued well past the 2008-2009 school year. Over time, the participation of school districts in St. Louis County decreased from 16 districts to 11 districts, and the number of students enrolled fell from its peak enrollment of 14,000 students to approximately 4,000 students (VICC, 2017). In 2016, the Board of Directors for the VICC program announced that they would no longer accept new students as of the 2023-2024 school year. Students already enrolled in the program 
and attending a participating county school would be able to continue through their graduation years (VICC, 2017).

When established in 1983, the goal of the VICC program was to promote desegregation in St. Louis County schools and the Urban School District, while encouraging movement of families in the community to locations outside of the St. Louis City. After 35 years, segregation continues to exist in the city and county areas, and the VICC Board of Directors have concluded that the program has not been effective in achieving it's intended purpose of encouraging members of the community to move their families and blend together in an integrated society (VICC, 2017). As the VICC program comes to a close, educators will be watching the effects on the students as they are reintroduced to a more segregated school system and community.

\section{Current Status of the VICC Program}

According to the Missouri Department of Elementary and Secondary Education (DESE) (2017), the Urban School District enrolled 24,496 pre-school through $12^{\text {th }}$ grade students in 2016. The district was comprised of 74 public, magnet, and alternative schools; further defined as 45 elementary schools, 9 middle schools, 14 high schools, and 6 alternative schools. Eighteen of the schools enrolled students in grades 9-12. However, only 3 high schools were considered traditional public schools. The other 15 were categorized as alternative, technical, magnet, or college-prep (SLPS, 2017).

In 2016, the VICC program enrolled 4,471 students in kindergarten through $12^{\text {th }}$ grade in one of 11 participating St. Louis County school districts (VICC, 2017). Families interested in enrolling their students in the VICC program must submit an application by June $30^{\text {th }}$ for the upcoming school year. Parents and students can list three districts of interest for placement purposes. VICC officials first determine placement by availability, then establish the appropriate school in the assigned district based on the student's address within the city of St. Louis. VICC 
divides the city into three attendance areas, or zones. Zone one contains addresses from the northeast boundary to mid-northwest boundary, not including downtown St. Louis. Zone two contains addresses from the mid-northwest boundary to the eastern edge, including downtown St. Louis. Addresses for the entire southern section of the city, not including the downtown area, are contained in zone 3. School districts receiving students from all three attendance areas have specific schools assigned per zone for ease of transportation, which is provided for free to families through state funding (VICC, 2017). If a family enrolled in the VICC program relocates to another residence within the city of St. Louis, the student remains enrolled. However, the student will have to attend the school assigned to that particular address and may result in the student being reassigned to another participating district within St. Louis County.

\section{Strengths and Concerns for the VICC Program}

\section{Strengths}

Through the research completed in this study, four main areas were identified as strengths for students enrolled in the VICC program. The first research question recommended an analysis of the attendance rates for VICC students enrolled in Suburban School District compared to their peers in Urban School District for 2014-2015, 2015-2016, and 2016-2017 school years. Using an analysis of variance (ANOVA), the proportional attendance rates for each school year were examined for the total student populations in SSD and USD, as shown in Table 1. The analysis

found statistically significant results at the .05 level. Resulting $p$-values of $p=0.013, p=0.007$, and $\mathrm{p}=0.026$ indicated a positive effect of the Suburban School District on student attendance rates. The null hypothesis was, therefore, rejected. The results of the analysis are shown in Table 2. 


\section{Table 2}

ANOVA Results for Attendance Rates

\begin{tabular}{|c|c|c|c|c|c|c|}
\hline & & $\begin{array}{l}\text { Sum of } \\
\text { Squares }\end{array}$ & df & Mean Square & $\mathrm{F}$ & Sig. \\
\hline \multirow{3}{*}{$\begin{array}{l}\text { Attendance Rate } 2014 \\
2015\end{array}$} & Between Groups & 1628.000 & 1 & 1628.000 & 14.178 & $* .013$ \\
\hline & Within Groups & 574.137 & 5 & 114.827 & & \\
\hline & Total & 2202.137 & 6 & & & \\
\hline \multirow{3}{*}{$\begin{array}{l}\text { Attendance Rate 2015- } \\
2016\end{array}$} & Between Groups & 242.080 & 1 & 242.080 & 19.981 & $* .007$ \\
\hline & Within Groups & 60.577 & 5 & 12.115 & & \\
\hline & Total & 302.657 & 6 & & & \\
\hline \multirow{3}{*}{$\begin{array}{l}\text { Attendance Rate 2016- } \\
2017\end{array}$} & Between Groups & 596.267 & 1 & 596.267 & 9.684 & $* .026$ \\
\hline & Within Groups & 307.870 & 5 & 61.574 & & \\
\hline & Total & 904.137 & 6 & & & \\
\hline
\end{tabular}

* .05 level of significance

The second research question analyzed the graduation rates of VICC students enrolled in SSD schools compared to their peers in USD for 2014-2015, 2015-2016, and 2016-2017 school years. Graduates were classified as students meeting state graduation requirements at the end of the $4^{\text {th }}$ year of high school. The graduation percentages for each school were found by taking the number of graduates divided by the total number of $12^{\text {th }}$ grade students. Statistical significance at the .05 level indicates a positive effect of Suburban School District on the graduation rates of students. The null hypothesis for the research question was rejected as the p-values for the analysis were $\mathrm{p}=.001, \mathrm{p}=.017$, and $\mathrm{p}=.001$. Results of the ANOVA can be found in Table 3 . 


\section{Table 3}

ANOVA Results for Graduation Rates

\begin{tabular}{|c|c|c|c|c|c|c|}
\hline & & Sum of Squares & df & Mean Square & $\mathrm{F}$ & Sig. \\
\hline \multirow[t]{3}{*}{ Graduation Rate 20142015 } & Between Groups & 1910.957 & 1 & 1910.957 & 41.597 & $* .001$ \\
\hline & Within Groups & 229.701 & 5 & 45.940 & & \\
\hline & Total & 2140.659 & 6 & & & \\
\hline \multirow[t]{3}{*}{ Graduation Rate 2015-2016 } & Between Groups & 862.401 & 1 & 862.401 & 12.268 & $* .017$ \\
\hline & Within Groups & 351.492 & 5 & 70.298 & & \\
\hline & Total & 1213.893 & 6 & & & \\
\hline \multirow[t]{3}{*}{ Graduation Rate 2016-2017 } & Between Groups & 2545.952 & 1 & 2545.952 & 54.979 & $* .001$ \\
\hline & Within Groups & 231.537 & 5 & 46.307 & & \\
\hline & Total & 2777.489 & 6 & & & \\
\hline
\end{tabular}

*.05 level of significance

The third research question analyzed the drop-out rates of VICC students enrolled in SSD compared to their peers in USD for the 2014-2015, 2015-2016, and 2016-2017 school years.

Statistical analysis found a positive relationship between Suburban School District and student drop-out rates. ANOVA results can be found in Table 4. Students attending SSD schools demonstrated a lower drop-out rate than their peers in USD. The null hypothesis was rejected, as all p-values of .000 were statistically significant at the .05 level.

\section{Table 4}

ANOVA Results for Drop Out Rates

\begin{tabular}{|c|c|c|c|c|c|c|}
\hline & & $\begin{array}{l}\text { Sum of } \\
\text { Squares }\end{array}$ & df & Mean Square & $\mathrm{F}$ & Sig. \\
\hline \multirow[t]{3}{*}{ Drop Out Rate 20142015} & Between Groups & 4171.768 & 1 & 4171.768 & 94.888 & $* .000$ \\
\hline & Within Groups & 219.825 & 5 & 43.965 & & \\
\hline & Total & 4391.592 & 6 & & & \\
\hline \multirow[t]{3}{*}{ Drop Out Rate 2015-2016 } & Between Groups & 986.058 & 1 & 986.058 & 136.080 & $* .000$ \\
\hline & Within Groups & 36.231 & 5 & 7.246 & & \\
\hline & Total & 1022.288 & 6 & & & \\
\hline \multirow[t]{3}{*}{ Drop Out Rate 2016-2017 } & Between Groups & 2208.773 & 1 & 2208.773 & 120.356 & $* .000$ \\
\hline & Within Groups & 91.760 & 5 & 18.352 & & \\
\hline & Total & 2300.533 & 6 & & & \\
\hline
\end{tabular}

*.05 level of signific ance

The fourth research question analyzed the ACT scores of VICC students enrolled in SSD compared to their peers in USD for the 2014-2015, 2015-2016, and 2016-2017 school years. 
Specifically, ACT scores for students in grade 12 during each school year were used for comparison and evaluation. The analysis shows a statistically significant relationship at the .05 level. The ANOVA results are shown in Table 5. P-values of $\mathrm{p}=.012, \mathrm{p}=.009$, and $\mathrm{p}=.026$ determined a positive effect of the Suburban School District on student ACT scores. As ACT scores showed greater gains for students in SSD, the null hypothesis was rejected.

\section{Table 5}

ANOVA Results for ACT Scores

\begin{tabular}{|c|c|c|c|c|c|c|}
\hline & & Sum of Squares & $\mathrm{df}$ & Mean Square & $\mathrm{F}$ & Sig. \\
\hline \multirow[t]{3}{*}{ ACT Scores 20142015} & Between Groups & 5.350 & 1 & 5.350 & 14.849 & $* .012$ \\
\hline & Within Groups & 1.802 & 5 & .360 & & \\
\hline & Total & 7.152 & 6 & & & \\
\hline \multirow[t]{3}{*}{ ACT Scores 2015-2016 } & Between Groups & 6.630 & 1 & 6.630 & 16.730 & $* .009$ \\
\hline & Within Groups & 1.982 & 5 & .396 & & \\
\hline & Total & 8.612 & 6 & & & \\
\hline \multirow[t]{3}{*}{ ACT Scores 2016-2017 } & Between Groups & 5.150 & 1 & 5.150 & 9.804 & $* .026$ \\
\hline & Within Groups & 2.627 & 5 & .525 & & \\
\hline & Total & 7.777 & 6 & & & \\
\hline
\end{tabular}

* .05 level of signific ance

\section{Concerns}

The final research question analyzed the EOC scores of VICC students enrolled in SSD compared to their peers in USD for the 2014-2015, 2015-2016, and 2016-2017 school years. The Algebra I and English II scores were only available for comparison from USD schools for the 2014-2016 school years. However, the Biology EOC exam scores were available for all 3 focus years. The analysis found statistically significant results at the .05 level in all but two EOC test score areas, the Language Arts EOC exams for the 2014-2015 and 2015-2016 school years. The ANOVA test results are shown in Table 6. The results show that the Suburban School District has a positive effect on students in the EOC exam areas of Algebra I and Biology. The null hypothesis is rejected for these two areas. However, EOC results for the English II exam are not 
statistically significant at the .05 level. Therefore, the null hypothesis for the research question is accepted.

\section{Table 6}

ANOVA Results for EOC Exams

\begin{tabular}{|c|c|c|c|c|c|c|}
\hline & & Sum of Squares & $\mathrm{df}$ & Mean Square & F & Sig. \\
\hline \multirow{3}{*}{$\begin{array}{l}\text { Algebra I EOC Exam } 2014 \\
2015\end{array}$} & Between Groups & 150.161 & 1 & 150.161 & 26.495 & $* .004$ \\
\hline & Within Groups & 28.338 & 5 & 5.668 & & \\
\hline & Total & 178.499 & 6 & & & \\
\hline \multirow{3}{*}{$\begin{array}{l}\text { Algebra I EOC Exam 2015- } \\
2016\end{array}$} & Between Groups & 145.413 & 1 & 145.413 & 7.906 & $* .037$ \\
\hline & Within Groups & 91.963 & 5 & 18.393 & & \\
\hline & Total & 237.375 & 6 & & & \\
\hline \multirow{3}{*}{$\begin{array}{l}\text { Biology EOC Exam } 2014 \\
2015\end{array}$} & Between Groups & 106.425 & 1 & 106.425 & 37.749 & $* .002$ \\
\hline & Within Groups & 14.096 & 5 & 2.819 & & \\
\hline & Total & 120.521 & 6 & & & \\
\hline \multirow{3}{*}{$\begin{array}{l}\text { Biology EOC Exam 2015- } \\
2016\end{array}$} & Between Groups & 203.301 & 1 & 203.301 & 22.291 & $* .005$ \\
\hline & Within Groups & 45.601 & 5 & 9.120 & & \\
\hline & Total & 248.901 & 6 & & & \\
\hline \multirow{3}{*}{$\begin{array}{l}\text { Biology EOC Exam 2016- } \\
2017\end{array}$} & Between Groups & 314.012 & 1 & 314.012 & 16.149 & $* .010$ \\
\hline & Within Groups & 97.222 & 5 & 19.444 & & \\
\hline & Total & 411.234 & 6 & & & \\
\hline \multirow{3}{*}{$\begin{array}{l}\text { English II EOC Exam } 2014 \\
2015\end{array}$} & Between Groups & 95.915 & 1 & 95.915 & 6.103 & .057 \\
\hline & Within Groups & 78.584 & 5 & 15.717 & & \\
\hline & Total & 174.499 & 6 & & & \\
\hline \multirow{3}{*}{$\begin{array}{l}\text { English II EOC Exam 2015- } \\
2016\end{array}$} & Between Groups & 27.727 & 1 & 27.727 & 1.656 & .254 \\
\hline & Within Groups & 83.694 & 5 & 16.739 & & \\
\hline & Total & 111.420 & 6 & & & \\
\hline
\end{tabular}

* .05 level of significance

\section{Implications}

The end of segregation through Brown and the continued presence of the achievement gap has led to the creation of alternative educational programs focused on student achievement, such as: desegregation programs, magnet schools, and charter schools (McCarthy, 2015). These programs were created throughout the United States in areas of segregation and poverty. In 1980, the desegregation program in St. Louis, Missouri, was established to integrate educational facilities and the larger community. African American students in the city of St. Louis could 
apply to attend participating school districts within the predominately white St. Louis County. In turn, students residing in St. Louis County could attend magnet or charter schools within the City of St. Louis. While integration was the main component of the desegregation program, a large focus of the program was providing African American and white students with equitable resources and experiences to assist in closing the achievement gap (VICC, 2017).

Since the beginning of the Voluntary Interdistrict Choice Corporation, over 60,000 students from the St. Louis area have been educated in schools within St. Louis County. Although the data in this study only provides the social and academic impact of the VICC program on Suburban School District high school students, one could ascertain that the same results could be found in one or more participating county districts.

\section{Researcher Recommendations}

High schools within the Suburban School District demonstrate a commitment to students participating in the Voluntary Interdistrict Choice Corporation desegregation program as evidenced through their social and academic success. VICC provides students with a unique opportunity to learn in communities different than their own. The skills acquired in the VICC program will continue to support the students and ensure their success in the school setting and beyond. The purpose of the researcher's analysis and recommendations is to provide feedback on the VICC program in participating school districts. After reviewing the literature, research, and data, the researcher has provided recommendations in the following areas of the VICC program: 1) Leadership, 2) Program Implementation and Education, and 3) Continuous Monitoring of the Program. 


\section{Recommendations for Leadership}

The mission statement of the Suburban School District is "we do whatever it takes to ensure all students reach their potential" (SSD, 2017). SSD has district and building leadership teams that are dedicated to students and their success. They have purposefully and effectively implemented the VICC program requirements as evidenced by social and academic impact data of students in SSD compared to their peers in Urban School District. The researcher recommends continuous analysis of data trends to assist in the determination of future programming related to the social and academic achievement of VICC students.

A second recommendation urges district and building leaders to analyze the social and academic impact data of other county school districts participating in the VICC program. This information can be used as a means to effectively communicate best practices in an effort to fully support VICC students. Understanding the experiences of neighboring districts through collaborative processes can provide leaders with valuable information when making decisions for program implementation.

Finally, district leaders are encouraged to ensure the continuation of staff buy-in of the VICC program. Students enrolled in VICC frequently need different levels of support and intervention than their peers who live within the participating school's attendance zone. Leaders need to encourage the willingness of teachers and staff members to reach students at their level of need academically, socially, emotionally, or behaviorally. Ongoing professional development opportunities should be provided for the support of the adults interacting regularly with VICC students.

\section{Recommendations for Program Implementation and Education}

Suburban School District demonstrates a solid success rate for students in several social and academic areas. Program implementation and education are important pieces in maintaining 
practices beneficial to all involved in the VICC program. To ensure continued success, the researcher provides several recommendations for consistency.

The history and longevity of the VICC program needs to be communicated on a consistent basis to students, staff, teachers, and community members. The researcher recommends professional development opportunities that provide staff members with information related to diversity, integration, and social justice. These broad topics can be further separated out as a reminder to staff of the social and academic needs of VICC students as they differ from their peers. Students traveling from one community to another to gain access to resources and education see their education through a different lens. Communication of student needs should be on-going and strategies for student growth should be discussed.

The second recommendation is for new staff members to be provided with in-depth training on the various aspects of the VICC program. Staff members new to the district should be assigned a mentor who specifically shares information about the VICC program - the history, enrollment procedures, attendance areas, transportation, and data analysis. Mentors should provide mentees with further information to increase knowledge of appropriate methods to build connections/relationships with VICC students as a means to broaden their educational experiences.

The researcher also recommends that all members of the school community know and understand the success rate of the VICC program in Suburban School District. Staff members often concentrate data analysis on their own subject areas. Breaking down academic data into a subset of VICC students can be helpful for staff when writing curriculum or creating innovative lessons for their students. Lessons can be focused on student interest and written at an appropriate level based on the student's prior knowledge. Furthermore, receiving feedback on 
student success provides teachers with validation that the program and their efforts are working effectively.

\section{Recommendations for Program Monitoring}

Monitoring is one of the most important aspects for the successful implementation of a program. It is the recommendation of the researcher that Suburban School District use the results of this study, as well as any other assessment data collected, as part of a continuous monitoring and evaluation process for the VICC program in Suburban School District. Extending the evaluation and education processes to community members is an important step when requesting input on program implementation.

Another recommendation provided by the researcher is to continuously monitor successes and failures for students in the VICC program. Successes and failures can take on many forms, including academic, social, or emotional needs. Timely awareness of these characteristics is essential for student growth and success. Needs can be targeted and intervention plans provided in an effort to provide judicious support for further growth.

The researcher also suggests consistent monitoring of social and academic data. The data should be shared with teachers and the team should continuously look for possible improvements in teaching and learning. Utilizing a method similar to response-to-intervention (RTI) to analyze VICC data intentionally targets strengths and weaknesses of students or systems. Regular meetings between VICC leaders and school staff to problem-solve for VICC students provides transparency and consistency for the health of the program. Additionally, frequent communication with students, parents, and staff is recommended by the researcher for the overall success of the program. 


\section{Conclusion}

The Voluntary Interdistrict Choice Corporation has demonstrated a positive effect on the social and academic impact data of students in Suburban School District. Students are excelling in the areas of attendance rates, graduation rates, drop-out rates, ACT scores, and EOC Biology I and Algebra I exam scores compared to their peers in the Urban School District. The researcher recognizes that this assessment provides a snapshot of the success that the VICC program has within the Suburban School District. Leaders are encouraged to analyze the data of neighboring school districts, seek best practices to enhance student learning, provide professional development to staff and community members, and collaborate with district officials.

In closing, the VICC program researcher would like to thank the administrators and staff of the Voluntary Interdistrict Choice Corporation, Urban School District, and Suburban School District for their willingness to participate in the evaluation of the VICC program. District administrators are committed to their students and are providing a meaningful educational experience. The research in this study proves that the VICC program provides students with the opportunity to thrive academically and socially through the continued support of dedicated staff, administrators, and community members. 


\section{References}

Diem, S. \& Brooks, J. (2013). Introduction to the issue on segregation, desegregation, and integration: from history, to policy, to practice. Teachers College Record, 115(11).

Graglia, L. A. (2014). The Supreme Court's perversion of the 1964 Civil Rights Act. Harvard Journal of Law \& Public Policy, 37(1), 103.

Grooms, A. A. (2016). Money or diversity? An implementation analysis of the Voluntary Transfer Program in St. Louis, 1999-2009. Education Policy Analysis Archives, 24(20).

Karatzas Konstantinos, D. (2016). Lyndon B. Johnson and the Civil Right Act of 1964. Vestnik Volgogradskogo Gosudarstvennogo Universiteta. Seriâ 4. Istoriâ, Regionovedenie, Meždunarodnye Otnošeniâ, 21(3), 25-33. doi:10.15688/jvolsu4.2016.3.3

Landmark Cases (2017). As retrieved from http://landmarkcases.org/en/landmark/cases/ brown_v_board_of_education\#Tab=Overview

Lawrence, A. (2012). Herbert Brownell, Jr.: The 'hidden hand' in the selection of Earl Warren and the government's role in Brown v. Board of Education. Journal of Supreme Court History, 37(1), 75-92. doi:10.1111/j.1540-5818.2012.01283.x

McCarthy, K. D. (2015). The battle of the branches: The impact of the judiciary and Title VI on desegregation in the American public school system. San Diego Law Review, 52(4), $967-$ 980.

Missouri Department of Elementary and Secondary Education (2018). Retrieved from http://dese.mo.gov

Rockwood School District (2017). Retrieved from www.rsdmo.org

Rothstein, R. (2015). The racial achievement gap, segregated schools, and segregated neighborhoods: A constitutional insult. Race and Social Problems, 7(1), 21-30. doi:10.1007/s12552-014-9134-1 
St. Louis Public Schools (2017). Retrieved from https://www.slps.org/domain/5110 Voluntary Interdistrict Choice Corporation (2017). Retrieved from http://www.choicecorp.org Welton, A. (2013). Even more racially isolated than before: Problematizing the vision for "diversity" in a racially mixed high school. Teachers College Record, 115(11), 1-42. 


\section{CHAPTER FIVE:}

CONTRIBUTION TO SCHOLARSHIP 


\title{
A Comparison of the Social and Academic Impact of High School Students Participating in Desegregation Programs to Their Peers
}

\begin{abstract}
The purpose of this quantitative study compares social and academic impact data of students enrolled in the St. Louis city desegregation program and their peers attending neighborhood district schools. The research analyzed student data for grades 9-12. Attendance rates, drop-out rates, graduation rates, ACT scores, and End of Course (EOC) exam scores were examined to determine if enrollment in the desegregation program had a positive or negative impact on students.

Study results found a statistically significant positive relationship between students enrolled in the VICC program and the social areas of attendance, drop-out, and graduation rates. A statistically significant positive relationship was also found between students enrolled in the VICC program and the academic areas of ACT and all but one area of the EOC scores. Although academic data was closer in comparison than social data, the relationship showed an overall positive statistical significance among VICC students.
\end{abstract}


In 1954, Supreme Court Justice, Earl Warren, penned the court's celebrated decision for Brown v. the Board of Education of Topeka, condemning traditions of Jim Crow that segregated access to education. He wrote, "We conclude that, in the field of public education, the doctrine of 'separate but equal' has no place. Separate educational facilities are inherently unequal" (Lawrence, 2012). As our nation approaches nearly 65 years of integration in education, an achievement gap continues to exist. Why? If all students are able to access the same level of education and resources for learning, shouldn't students be learning at the same rate? If our schools are fully integrated, why do programs designed to encourage integration within our communities continue to not only exist, but receive state and federal funding or contributions from private entities?

In the city of St. Louis, Missouri, African American students have several options when it comes to their education. Students can choose to attend schools within their neighborhood district, magnet or charter schools, or enroll in the city's desegregation program, the Voluntary Interdistrict Choice Corporation (VICC). Each year, new students are selected from a lottery joining the approximate 4,000 VICC students attending St. Louis County elementary, middle, and high schools located within a 30-mile radius from their homes (VICC, 2017). Students enrolling with VICC must understand the requirements of the program and be willing to commit to an altered school day compared to their peers attending schools near home. A typical day for VICC students begins with a 40 to 75 -minute bus ride to school. These young men and women attend classes, then frequently stay after school for extra help on assignments before returning home late in the afternoon. Middle and high school students participating in extracurricular sports or activities ride the evening school bus or a taxicab home, often arriving after 9:00 pm. They eat dinner, complete homework, and wake up the following morning to repeat the entire 
process. Students participating in desegregation programs dedicate a tremendous amount of time to attend schools outside of their neighborhood school districts. Has the VICC desegregation program had a positive social and academic impact on participating students?

The research in this document is designed to provide a greater understanding of the effectiveness of desegregation programs by offering a comparison of the social and academic impact data. The study compares students enrolled in a desegregation program, specifically in St. Louis County, Missouri, and attending high schools in Suburban School District (SSD), with students enrolled in their home public schools within the Urban School District (USD) in the city of St. Louis. Using quantitative research methods, the researcher presents findings comparing social and academic impact data, with recommendations for future development to further close the academic achievement gap.

\section{Research Questions and Hypotheses}

There are five main research questions guiding this study, with each question focusing on specific social and academic impact data. The questions and hypotheses are as follows:

Q1: What is the difference in the attendance rates of African American students in grades 912 enrolled in the Voluntary Interdistrict Choice Corporation desegregation program, as compared to students in grades 9-12 enrolled in the Urban School District?

H1: It is predicted that the attendance rates will show a positive statistical significance for VICC students attending Suburban School District high schools.

Q2: What is the difference in the graduation rates of African American students in grades 912 enrolled in the Voluntary Interdistrict Choice Corporation desegregation program, as compared to students in grades 9-12 enrolled in the Urban School District?

$\mathrm{H} 2$ : It is predicted that the graduation rates will show a positive statistical significance for 
VICC students attending Suburban School District high schools.

Q3: What is the difference in the drop-out rates of African American students in grades 9-12 enrolled in the Voluntary Interdistrict Choice Corporation desegregation program, as compared to students in grades 9-12 enrolled in the Urban School District?

H3: It is predicted that the drop-out rates will show a positive statistical significance for VICC students attending Suburban School District high schools.

Q4: What is the difference in the ACT scores of African American students in grades 9-12 enrolled in the Voluntary Interdistrict Choice Corporation desegregation program, as compared to students in grades 9-12 enrolled in the Urban School District?

H4: It is predicted that the ACT scores will show a positive statistical significance for VICC students attending Suburban School District high schools.

Q5: What is the difference in the End-of-Course (EOC) exam scores of African American students in grades 9-12 enrolled in the Voluntary Interdistrict Choice Corporation desegregation program, as compared to students in grades 9-12 enrolled in the Urban School District?

H5: It is predicted that the EOC scores will show a positive statistical significance for VICC students attending Suburban School District high schools.

Following Brown, desegregation did not begin automatically or easily. There were many forms of descent including various legal battles, direct disobedience, subversion, and demonstrations. These activities spanned across the country, primarily in the southern United States. Most notable situations arose in states like Arkansas, Virginia, and Missouri. Stories of segregation were commonplace and several equity-based complaints were filed with the court system during the years following the Brown decision, causing new policies to be written and 
others rewritten before desegregation efforts occurred throughout the nation (Diem \& Brooks, 2013). One of the most important moments in the civil rights movement was the passage of the

Civil Rights Act on June 2, 1964, which outlawed racial discrimination and banned prejudice. It stated the following:

All persons shall be entitled to the full and equal enjoyment of the goods, services, facilities, and privileges, advantages, and accommodations of any place of public accommodation, as defined in this section, without discrimination or segregation on the ground of race, color, religion, or national origin (Karatzas Konstantinos , 2016, p. 31). Although the Civil Rights Act of 1964 eventually ended segregation practices in schools, political leaders quickly began to realize that segregated neighborhoods preserved the lack of integration in student populations. Rothstein (2015) states, "Education policy is constrained by housing policy: it is not possible to desegregate schools without desegregating both low-income and affluent neighborhoods (p. 21). In discussions of potential solutions, political leaders realized that bussing students was a viable option as it was successful in previous years during times of mandated segregation (Graglia, 2014).

\section{Social Justice and Equity in Education}

The lens used to frame this research was focused on social justice with an emphasis on equity in education by highlighting legal, socioeconomic influence, and the achievement gap. Martin \& Ngcobo (2015) define social justice as the "full and equal participation of all groups in society that is mutually shaped to meet their needs" (p.89). As our society continues to challenge practices and procedures to be more accepting and inclusive of all citizens, there is still much work that needs to be done. Logan (2016) states, "high school segregation persists in the United States despite attempts to desegregate schools... after the Brown vs Board of Education decision" 
(p. 324). Although many schools have diverse populations, they continue to face the difficult challenge of learning, understanding, and implementing components of desegregation. Educators have to be willing to develop curriculum that maintains respectful acceptance among students while providing a solid and inclusive learning environment that will help to close the achievement gap (Welton, 2013). Unintentional segregation continues to exist in many areas of our country, and the achievement gap continues to plague our students. (McCarthy, 2015).

\section{Voluntary Interdistrict Choice Corporation}

In 1972, a group of parents from St. Louis, Missouri, filed a class action lawsuit stating that students in the city were not receiving the same level of education as students in St. Louis County (Grooms, 2016). In 1980, the U. S. Court of Appeals upheld the lawsuit declaring that both the State of Missouri and the Urban School District Board of Education were accountable for perpetuating a segregated school system. In 1983, a settlement agreement was created allowing for African American students residing in the city of St. Louis to attend participating schools within St. Louis County, while concurrently allowing white students in St. Louis County to attend magnet schools in the City of St. Louis (Grooms, 2016). The State of Missouri agreed to cover the cost of the program and transportation; and indicated a goal of the state to attain a population of at least 25\% African American students in attendance in county schools (VICC, 2016).

In 1999, the non-profit, Voluntary Interdistrict Choice Corporation (VICC), was recognized as the manager of the desegregation program through the intended end of the program in the 2008-2009 school year. Through two separate votes by the VICC Board of Directors, the VICC desegregation program was granted extension and continued well past the 2008-2009 school year. During that time, the participation of school districts in St. Louis County 
decreased from 16 districts to 11 districts, and the number of students enrolled fell from its peak enrollment of 14,000 students in 1998 to approximately 4,000 students in 2017 (VICC, 2017). In November 2016, the Board of Directors for the VICC program announced that they would no longer accept new students after the 2023-2024 school year. Students already enrolled in the program and attending a participating county school could continue through their high school graduation years (VICC, 2017). As the VICC program comes to a close, educators will be watching the effects on the students and their achievement as they are reintroduced to a more segregated, more populated school system and community.

\section{Achievement Gap}

Although integration has been present in our society for approximately sixty years, historical practices have perpetuated the achievement gap between white and African American students. According to Harackiewicz, et. al. (2015), "these achievement gaps can be attributed to a number of economic and social factors such as poverty, quality of schools, economic resources, and academic preparation" (p. 745).

During times of segregation, African American families often lived in areas of lowincome housing and high poverty, and did not have access to the same resources as many white families. Students traveled far distances to reach their designated schools, and were frequently absent due to responsibilities at home or illnesses related to poor healthcare (Rothstein, 2015). Rothstein (2015) suggests that students living in such conditions for multiple generations add additional barriers to their achievement, including: familial experiences, the absence of enrichment opportunities, greater illiteracy among parents, and lack of resources.

Kotok (2017) states that the "achievement gap persists because minority students are more likely to enter high school without the necessary skills" (p. 183). Educators must begin the 
school year with remediation lessons, not allowing high achieving students to be challenged.

Student mobility creates the need for teachers to spend valuable time re-teaching lessons to new students, taking time away from creating and delivering innovative lessons with a goal of reaching all levels of learners.

When reflecting on the judgement made by the Supreme Court in the case of Brown, Palardy, Rumberger, \& Butler (2015) state that the "decision was not based solely upon the notion that segregated black schools were inferior in terms of academic instruction, curricular rigor, resources, etc., but also on research that showed segregating black children had negative social-emotional and behavioral consequences" (p. 1). Low-income neighborhoods are frequently surrounded by violence and crime, creating stress for students and impacting their learning (Rothstein, 2016). Jones \& Schindler (2015) suggest that strong school climates have a positive effect on student achievement. Solid connections to quality teachers reduces stress by building relationships and trust, which leads to higher student achievement. Research indicates that quality teachers are unequally distributed. Stronger teachers are moving to districts with more resources and better compensation (Downey \& Condron, 2016). Peterson, et. al. (2016) suggest that teacher expectations are imperative to the academic success of students. When teachers provide students with high-level opportunities in a fair and supportive environment, students of all genders and ethnicities will respond with higher levels of learning.

The end of segregation through Brown and the continued presence of the achievement gap has led to the creation of alternative educational programs focused on student achievement, such as: desegregation programs, magnet schools, and charter schools (McCarthy, 2015). These programs were created throughout the United States in areas of segregation and poverty. 
However, the creation of alternative education programs did not always have the desired effect on student achievement. Gamoran \& An (2016) state the following regarding magnet schools: As the academically selective magnet schools are becoming more White, and the nonselective magnets are increasingly Black, one may speculate that magnet schools may contribute to wider achievement gaps - not because of the effects of magnet schools per se, but because they constitute a form of between-school tracking which, because Whites tend to be over-enrolled and Blacks under-enrolled in the most selective locations, magnifies the overall achievement gap (p. 47).

Chu (2011) said, "The racial achievement gap reflects the inequality in educational experience" (p.202). State and federal programs, such as No Child Left Behind (NCLB) and Race to the Top (RTTT), were created in an effort to bring the achievement gap in focus and designed standards to target the learning of all students (Kotok, 2017).

Kim, Turner, \& Yazdian (2014) agree that teachers have lost the ability to use their innovative teaching techniques in the classroom, as educators often feel that they must teach to the test. For students entering high school with gaps in their knowledge, this method of teaching has been detrimental. Kim, Turner, \& Yazdian (2014) state that "educational reforms intend to make changes in the way students learn, but often miss the mark by focusing on tasks that do not bring real educational benefits to students and teachers" (p. 173).

\section{Design of the Study}

In an attempt to further understand the social and academic impact of students enrolled in the VICC program compared to their peers enrolled in Urban School District, the researcher completed a quantitative study. Information was obtained from two main sources: 1) the 
Missouri Department of Elementary and Secondary Education and 2) the Suburban School District, a VICC program participant.

The research compares the social and academic impact data of two core groups of students. They are: 1) students in grades 9-12 within the city of St. Louis, Missouri, enrolled in Urban School District, and 2) African American students in grades 9-12 from the city of St. Louis, Missouri, enrolled in the VICC desegregation program and attending schools in Suburban School District in St. Louis County. According to the Missouri Department of Elementary and Secondary Education (DESE) (2017), the Urban School District enrolled 24,496 pre-school through $12^{\text {th }}$ grade students in 2016 . The district was comprised of 74 public, magnet, and alternative schools; further defined as 45 elementary schools, 9 middle schools, 14 high schools, and 6 alternative schools. Eighteen of the schools enrolled students in grades 9-12. However, only 3 high schools were considered traditional public schools. The other 15 were categorized as alternative, technical, magnet, or college-prep (SLPS, 2017).

In 2016, the VICC program enrolled a total of 4,471 students in kindergarten through $12^{\text {th }}$ grade in 11 participating St. Louis County school districts (VICC, 2017). Families interested in enrolling their students in the VICC program must submit an application by June $30^{\text {th }}$ for the upcoming school year. Parents and students can list three districts of interest for placement purposes. VICC officials first determine placement by availability, then finalize the appropriate school in the assigned district based on the student's address within the city of St. Louis. VICC divides the city into three attendance areas, or zones. Zone one contains addresses from the northeast boundary to mid-northwest boundary, not including downtown St. Louis. Zone two contains addresses from the mid-northwest boundary to the eastern edge, including downtown St. Louis. Addresses for the entire southern section of the city, not including the downtown area, are 
contained in zone 3. School districts receiving students from all three attendance areas have specific schools assigned per zone for ease of transportation, which is provided for free to families through state funding (VICC, 2017). If a family enrolled in the VICC program relocates to another residence within the city of St. Louis, the student remains enrolled. However, the student will have to attend the school assigned to that particular address and may result in the student being reassigned to another participating district within St. Louis County.

This study reviews longitudinal data for three consecutive school years: 2014-2015, 2015-2016, and 2016-2017. The researcher utilized the Missouri Department of Elementary and Secondary Education to access school and district report card data for attendance rates, graduation rates, drop-out rates, ACT scores and EOC scores for students in USD. The same data for VICC students enrolled in SSD was obtained from the district data department. This information needed to be further analyzed in order to separate data for African American students enrolled in the VICC program from non-VICC African American students who reside in St. Louis County.

Student enrollment numbers for the three focus years of the study were evaluated using descriptive statistics, and are displayed in Table 1. Social and academic impact data was analyzed using the IBM software program, Statistical Package for the Social Sciences (SPSS). The researcher utilized the one-way ANOVA feature of SPSS to compare means of the independent variables to determine an existence of statistical significance in the data. ANOVA output for each data set was placed in tabular format to expedite analysis of the data. After examination of data and determination of the results, the researcher shared the outcomes with educational stakeholders in the Voluntary Interdistrict Choice Corporation, Urban School 
District, Suburban School District, the Missouri Department of Elementary and Secondary

Education, as well as other interested members of the education community.

\section{Participants}

African American students in the Suburban School District were separated to create a subset of students including only participants in the Voluntary Interdistrict Choice Corporation from all four high schools. The comparison group of Urban School District students included the entire population of students from the three public high schools in the district. The participant populations from each school and year can be found in Table 1. The four Suburban high schools used for the study are coded as: SSD1, SSD2, SSD3, and SSD4. The total population for all four high schools is listed. Urban School District high school are shown as: USD1, USD2, and USD3. The total population for each school year is also shown in Table 1.

\section{Table 1}

Population of SSD and USD High Schools per School Year of Study

\begin{tabular}{lcccrrrrrr}
\hline School Year & SSD 1 & SSD 2 & SSD 3 & SSD 4 & SSD Total & USD 1 & USD 2 & USD 3 & USD Total \\
\hline $2014-2015$ & 206 & 464 & 300 & 216 & 1186 & 625 & 440 & 645 & 1710 \\
$2015-2016$ & 198 & 255 & 414 & 190 & 1057 & 518 & 356 & 616 & 1490 \\
$2016-2017$ & 173 & 220 & 331 & 157 & 881 & 462 & 320 & 510 & 1292 \\
\hline
\end{tabular}

\section{Data Collection Tools}

Social and academic impact numbers were obtained from the Missouri Department of Elementary and Secondary Education and Suburban School District. Data included proportional attendance rates, graduation rates, drop-out rates, ACT scores, and EOC exam scores. The data for the students participating in the VICC program and attending SSD was not readily available through DESE. Instead, this data was provided by SSD district officials using non-identifiable codes for each school and category. Information for USD students was predominately obtained through individual school report cards accessed through DESE, with two areas of EOC data 
acquired from USD. All data was entered in the IBM SPSS program using non-identifiable numbers for each of the seven schools used in the study.

\section{Data Analysis}

Social and academic impact data was evaluated through an analysis of variance (ANOVA) completed with IBM SPSS software. Social impact data was identified as attendance rates, graduation rates, and drop-out rates. ACT scores and EOC exam scores were categorized as academic data. The EOC exam scores were incomplete for Algebra I and English II for the 2016-2017 school year, only allowing two years to be analyzed through IBM SPSS.

Five separate ANOVA tests were conducted to determine results of the research questions. The initial ANOVA test compared the means of the attendance rates for students in SSD to students in USD. The second test compared the means of the graduation rates, while the third showed the relationship of drop-out rates for students in SSD compared to students in USD. The fourth and fifth ANOVA tests compared the means of ACT scores and EOC exam scores between students in SSD and USD. Results for all tests can be found in tabular format within the findings.

\section{Findings}

The first research question recommended an analysis of the attendance rates for VICC students enrolled in Suburban School District compared to their peers in Urban School District for the 2014-2015, 2015-2016, and 2016-2017 school years. Using an analysis of variance (ANOVA), the proportional attendance rates for each school year were examined for the total student populations in SSD and USD, as shown in Table 1. The analysis found statistically significant results at the .05 level. Resulting $p$-values of $p=0.013, p=0.007$, and $p=0.026$ 
indicated a positive effect of the Suburban School District on student attendance rates. The null hypothesis was, therefore, rejected. The results of the analysis are shown in Table 2.

\section{Table 2}

ANOVA Results for Attendance Rates

\begin{tabular}{|c|c|c|c|c|c|c|}
\hline & & $\begin{array}{l}\text { Sum of } \\
\text { Squares }\end{array}$ & $\mathrm{df}$ & Mean Square & $\mathrm{F}$ & Sig. \\
\hline \multirow{3}{*}{$\begin{array}{l}\text { Attendance Rate } 2014 \\
2015\end{array}$} & Between Groups & 1628.000 & 1 & 1628.000 & 14.178 & $* .013$ \\
\hline & Within Groups & 574.137 & 5 & 114.827 & & \\
\hline & Total & 2202.137 & 6 & & & \\
\hline \multirow{3}{*}{$\begin{array}{l}\text { Attendance Rate } 2015 \text { - } \\
2016\end{array}$} & Between Groups & 242.080 & 1 & 242.080 & 19.981 & $* .007$ \\
\hline & Within Groups & 60.577 & 5 & 12.115 & & \\
\hline & Total & 302.657 & 6 & & & \\
\hline \multirow{3}{*}{$\begin{array}{l}\text { Attendance Rate } 2016 \text { - } \\
2017\end{array}$} & Between Groups & 596.267 & 1 & 596.267 & 9.684 & $* .026$ \\
\hline & Within Groups & 307.870 & 5 & 61.574 & & \\
\hline & Total & 904.137 & 6 & & & \\
\hline
\end{tabular}

* .05 level of signific ance

The second research question analyzed the graduation rates of VICC students enrolled in SSD schools compared to their peers in USD for the 2014-2015, 2015-2016, and 2016-2017 school years. Graduates were classified as students meeting state graduation requirements at the end of the $4^{\text {th }}$ year of high school. The graduation percentages for each school were found by taking the number of graduates divided by the total number of $12^{\text {th }}$ grade students. Statistical significance at the .05 level indicate a positive effect of Suburban School District on the graduation rates of students. The null hypothesis for the research question was rejected as the pvalues for the analysis were $\mathrm{p}=.001, \mathrm{p}=.017$, and $\mathrm{p}=.001$. Results of the ANOVA can be found in Table 3. 


\section{Table 3}

ANOVA Results for Graduation Rates

\begin{tabular}{|c|c|c|c|c|c|c|}
\hline & & Sum of Squares & df & Mean Square & $\mathrm{F}$ & Sig. \\
\hline \multirow[t]{3}{*}{ Graduation Rate 20142015 } & Between Groups & 1910.957 & 1 & 1910.957 & 41.597 & $* .001$ \\
\hline & Within Groups & 229.701 & 5 & 45.940 & & \\
\hline & Total & 2140.659 & 6 & & & \\
\hline \multirow[t]{3}{*}{ Graduation Rate 2015-2016 } & Between Groups & 862.401 & 1 & 862.401 & 12.268 & $* .017$ \\
\hline & Within Groups & 351.492 & 5 & 70.298 & & \\
\hline & Total & 1213.893 & 6 & & & \\
\hline \multirow[t]{3}{*}{ Graduation Rate 2016-2017 } & Between Groups & 2545.952 & 1 & 2545.952 & 54.979 & $* .001$ \\
\hline & Within Groups & 231.537 & 5 & 46.307 & & \\
\hline & Total & 2777.489 & 6 & & & \\
\hline
\end{tabular}

*.05 level of signific ance

The third research question analyzed the drop-out rates of VICC students enrolled in SSD compared to their peers in USD for the 2014-2015, 2015-2016, and 2016-2017 school years.

Statistical analysis found a positive relationship between Suburban School District and student drop-out rates. ANOVA results can be found in Table 4. Students attending SSD schools demonstrated a lower drop-out rate than their peers in USD. The null hypothesis was rejected, as all $\mathrm{p}$-values of $\mathrm{p}=.000$ were statistically significant at the .05 level.

\section{Table 4}

ANOVA Results for Drop Out Rates

\begin{tabular}{|c|c|c|c|c|c|c|}
\hline & & $\begin{array}{l}\text { Sum of } \\
\text { Squares }\end{array}$ & df & Mean Square & $\mathrm{F}$ & Sig. \\
\hline \multirow[t]{3}{*}{ Drop Out Rate 20142015} & Between Groups & 4171.768 & 1 & 4171.768 & 94.888 & $* .000$ \\
\hline & Within Groups & 219.825 & 5 & 43.965 & & \\
\hline & Total & 4391.592 & 6 & & & \\
\hline \multirow[t]{3}{*}{ Drop Out Rate 2015-2016 } & Between Groups & 986.058 & 1 & 986.058 & 136.080 & $* .000$ \\
\hline & Within Groups & 36.231 & 5 & 7.246 & & \\
\hline & Total & 1022.288 & 6 & & & \\
\hline \multirow[t]{3}{*}{ Drop Out Rate 2016-2017 } & Between Groups & 2208.773 & 1 & 2208.773 & 120.356 & $* .000$ \\
\hline & Within Groups & 91.760 & 5 & 18.352 & & \\
\hline & Total & 2300.533 & 6 & & & \\
\hline
\end{tabular}

*.05 level of signific ance

The fourth research question analyzed the ACT scores of VICC students enrolled in SSD compared to their peers in USD for the 2014-2015, 2015-2016, and 2016-2017 school years. 
ACT scores for students in grade 12 during each school year were used specifically for comparison and evaluation. The analysis shows a statistically significant relationship at the .05 level, as shown in the ANOVA results Table 5. P-values of $\mathrm{p}=.012, \mathrm{p}=.009$, and $\mathrm{p}=.026$ determined a positive effect of the Suburban School District on student ACT scores. As ACT scores showed greater gains for students in SSD, the null hypothesis was rejected.

\section{Table 5}

ANOVA Results for ACT Scores

\begin{tabular}{|c|c|c|c|c|c|c|}
\hline & & Sum of Squares & $\mathrm{df}$ & Mean Square & $\mathrm{F}$ & Sig. \\
\hline \multirow[t]{3}{*}{ ACT Scores 20142015} & Between Groups & 5.350 & 1 & 5.350 & 14.849 & $* .012$ \\
\hline & Within Groups & 1.802 & 5 & .360 & & \\
\hline & Total & 7.152 & 6 & & & \\
\hline \multirow[t]{3}{*}{ ACT Scores 2015-2016 } & Between Groups & 6.630 & 1 & 6.630 & 16.730 & $* .009$ \\
\hline & Within Groups & 1.982 & 5 & .396 & & \\
\hline & Total & 8.612 & 6 & & & \\
\hline \multirow[t]{3}{*}{ ACT Scores 2016-2017 } & Between Groups & 5.150 & 1 & 5.150 & 9.804 & $* .026$ \\
\hline & Within Groups & 2.627 & 5 & .525 & & \\
\hline & Total & 7.777 & 6 & & & \\
\hline
\end{tabular}

*.05 level of significance

The final research question analyzed the EOC scores of VICC students enrolled in SSD compared to their peers in USD for the 2014-2015, 2015-2016, and 2016-2017 school years. The Algebra I and English II scores were only available for comparison from USD schools for the 2014-2016 school years. However, the Biology EOC exam scores were available for all 3 focus years. The analysis found statistically significant results at the .05 level in all but two EOC test score areas, the Language Arts EOC exams for the 2014-2015 and 2015-2016 school years. The ANOVA test results are shown in Table 6. The results show that the Suburban School District has a positive effect on students in the EOC exam areas of Algebra I and Biology. The null hypothesis is rejected for these two areas. However, EOC results for the English II exam are not 
statistically significant at the .05 level. Therefore, the null hypothesis for the research question is accepted.

\section{Table 6}

ANOVA Results for EOC Exams

\begin{tabular}{|c|c|c|c|c|c|c|}
\hline & & Sum of Squares & df & Mean Square & $\mathrm{F}$ & Sig. \\
\hline \multirow{3}{*}{$\begin{array}{l}\text { Algebra I EOC Exam } 2014 \\
2015\end{array}$} & Between Groups & 150.161 & 1 & 150.161 & 26.495 & $* .004$ \\
\hline & Within Groups & 28.338 & 5 & 5.668 & & \\
\hline & Total & 178.499 & 6 & & & \\
\hline \multirow{3}{*}{$\begin{array}{l}\text { Algebra I EOC Exam 2015- } \\
2016\end{array}$} & Between Groups & 145.413 & 1 & 145.413 & 7.906 & $* .037$ \\
\hline & Within Groups & 91.963 & 5 & 18.393 & & \\
\hline & Total & 237.375 & 6 & & & \\
\hline \multirow{3}{*}{$\begin{array}{l}\text { Biology EOC Exam } 2014 \\
2015\end{array}$} & Between Groups & 106.425 & 1 & 106.425 & 37.749 & $* .002$ \\
\hline & Within Groups & 14.096 & 5 & 2.819 & & \\
\hline & Total & 120.521 & 6 & & & \\
\hline \multirow{3}{*}{$\begin{array}{l}\text { Biology EOC Exam 2015- } \\
2016\end{array}$} & Between Groups & 203.301 & 1 & 203.301 & 22.291 & $* .005$ \\
\hline & Within Groups & 45.601 & 5 & 9.120 & & \\
\hline & Total & 248.901 & 6 & & & \\
\hline \multirow{3}{*}{$\begin{array}{l}\text { Biology EOC Exam 2016- } \\
2017\end{array}$} & Between Groups & 314.012 & 1 & 314.012 & 16.149 & $* .010$ \\
\hline & Within Groups & 97.222 & 5 & 19.444 & & \\
\hline & Total & 411.234 & 6 & & & \\
\hline \multirow{3}{*}{$\begin{array}{l}\text { English II EOC Exam } 2014 \\
2015\end{array}$} & Between Groups & 95.915 & 1 & 95.915 & 6.103 & .057 \\
\hline & Within Groups & 78.584 & 5 & 15.717 & & \\
\hline & Total & 174.499 & 6 & & & \\
\hline \multirow{3}{*}{$\begin{array}{l}\text { English II EOC Exam 2015- } \\
2016\end{array}$} & Between Groups & 27.727 & 1 & 27.727 & 1.656 & .254 \\
\hline & Within Groups & 83.694 & 5 & 16.739 & & \\
\hline & Total & 111.420 & 6 & & & \\
\hline
\end{tabular}

* .05 level of signific ance

\section{Discussion}

Study results show a statistically significant positive relationship between Suburban School District and student attendance in the first research question. An analysis of variance was also used to study the social impact of graduation rates and drop-out rates. Research questions two and three examined these relationships and found a positive effect of the Suburban School District on student graduation rates and drop-out rates. ANOVA results showed statistical significance in all areas of social impact data. Therefore, the null hypotheses for research questions 1, 2, and 3 were rejected. Academic data in the areas of ACT and EOC exam scores 
were studied for statistical significance. ANOVA results for research question 4 showed a positive statistical significance between Suburban School District and ACT scores. The null hypothesis was rejected. For the final research question, positive statistical significance was found in all Algebra I and Biology EOC scores showing a positive effect of Suburban School District on exam scores. Although a negative statistical significance was found for the English II EOC exams, the scores between the two school districts were close. For the 2014-2015 school year, the p-value for English II was p=.57. The 2015-2016 English II p-value showed the largest gap at $p=.254$. As these two areas resulted in a negative statistical significance, the null hypothesis for research question 5 was accepted.

Study results established a positive relationship between Suburban School District and student social and academic impact data. The data from this research study shows that students enrolled in the VICC program are succeeding at a higher rate than their peers in the Urban School District. This leads to an understanding that not only is the desegregation program working for these students, but steps are being taken to close the achievement gap between white and African American students. Welton (2013) states that desegregation programs are a benefit to all students involved. Students learn diversity, cultural characteristics of others, acceptance, and tolerance. Desegregation and the achievement gap are both areas of focus for staff and students, and inclusivity is a priority in order to provide a positive educational opportunity for all.

In a November 2016 news article in the St. Louis Post-Dispatch, the decision to end the VICC program was a topic of interest. Area superintendents discussed their concern for terminating a program which has educated over 60,000 students since 1982. District leaders agreed that the desegregation program has had a significant impact on student success since its 
beginning, and believe in the importance of replacing the VICC program with another system to assist students in their learning (Taketa, 2016). The 2023-2024 school year will mark the official end of new enrollments to the VICC program in St. Louis, although students will have the opportunity to remain in their designated schools through their graduation years. Kindergartners starting in the 2023-2024 school year will graduate in 2036, which will signify the official close of the VICC program.

Research indicates that students enrolled in the VICC program are thriving compared to their peers in the Urban School District. More students are attending school on a regular basis, with a near $100 \%$ graduation rate. The social aspects contribute to higher academic data, proving that students are immersed in high levels of learning. The St. Louis desegregation demonstrates that it is a positive experience for students while effectively closing the achievement gap.

Eliminating the VICC program altogether will not only remove the opportunity for students to participate in culturally mixed schools, but it will also take away the ability for students to access an education that allows them to thrive.

\section{Limitations}

Analyzing the social and academic impact of two different school districts was a natural limitation of the research study. School settings were markedly different when comparing the socio-economic status between the SSD and USD communities. Median household incomes were much higher in SSD and the free and reduced status for students was lower. Additionally, students from both school districts had access to different levels of curriculum and academic rigor, teaching styles, and enrichment opportunities.

A second limitation for the study was the absence of the 2016-2017 English II EOC and Algebra I exam score data for all 3 USD schools. This information could provide further 
knowledge and understanding of the discrepancies between the English II test scores compared to the Algebra I and Biology EOC exam scores. Further, it could lead to a discovery as to whether or not the mathematics results would show a consistent positive effect of the SSD high schools on student achievement gains.

\section{Implications for Future Research}

Logan (2016) states, "high school segregation persists in the United States despite attempts to desegregate schools" (p. 324). Inequity continues to plague our education system, which perpetuates the achievement gap and need of families to look for alternate educational placements outside of their neighborhood schools. After six decades of focusing on desegregation in our schools, African American students are still searching for a better educational opportunity. In many cases, students are leaving their home schools in impoverished neighborhoods to attend those in predominantly white suburbia, knowing the potential presence of more funding and better resources for a quality education (Welton, 2013).

Analyzing the social and academic impact data of the VICC desegregation program captures only a small portion of a student's overall success. It does not account for rigor of the curriculum, social and emotional impact, or post-secondary success. Further exploration of these topics could provide a better understanding of the total effect of desegregation programs on the success of students.

The rigor of curriculum on the success of students is a potential area for further study. Research indicates that African American students frequently do not enroll in honors or advanced placement (AP) courses, and are not challenged to do so. Educators must concentrate on intentionally changing the culture of the school community to acknowledge that all students are capable of learning at high rates (Welton, 2013). Researching further into this phenomenon 
could provide stakeholders in education with knowledge of rigor and its impact on student learning.

Understanding the social and emotional needs of students and adaptation skills another important area of study. Students enrolled in the VICC desegregation program live in low socioeconomic communities and attend schools in districts quite the opposite, causing students to feel as if they are living two separate lives. Research on social and emotional data and adaptation skills could provide valuable information about the differences in communities, community experiences, and resources available within the school to create a safe and trusting environment.

Evaluating post-secondary success of students enrolled in the VICC program could potentially provide the researcher with the most influential impact of the VICC program on students. The researcher could examine post-secondary education choices - technical, community college, trade school, military, 4-year university, employment, or none of these options. This study could go further by gathering information of jobs obtained, current salary, and highest academic degree obtained.

The VICC program works in partnership with county school districts to provide students from the city of St. Louis with the opportunity to access resources, cultural backgrounds, and educational experiences unlike their peers in the Urban School District. Through integration and opportunity, VICC has demonstrated the ability to accomplish the hope set forth by the Brown decision. Students who have the ability to participate in this program will have a statistically better chance to flourish academically and socially. Local school authorities must work with state and government officials to look for ways to extend or alter the program to continue providing students with this proven system of education. 


\section{References}

Chu, S. (2011). Perspectives in understanding the schooling and achievement of students from culturally and linguistically diverse backgrounds. Journal of Instructional Psychology, 38(3/4), 201-209.

Diem, S. \& Brooks, J. (2013). Introduction to the issue on segregation, desegregation, and integration: from history, to policy, to practice. Teachers College Record, 115(11).

Downey, D. B., \& Condron, D. J. (2016). Fifty years since the Coleman report: Rethinking the relationship between schools and inequality. Sociology of Education, 89(3), 207-220. doi:10.1177/0038040716651676

Gamoran, A. \& An, B. (2016). Effects of school segregation and school resources in a changing policy context. Educational Evaluation and Policy Analysis, 38(1), 43-64. doi:10.3102/0162373715585604

Graglia, L. A. (2014). The Supreme Court's perversion of the 1964 Civil Rights Act. Harvard Journal of Law \& Public Policy, 37(1), 103.

Grooms, A. A. (2016). Money or diversity? An implementation analysis of the Voluntary Transfer Program in St. Louis, 1999-2009. Education Policy Analysis Archives, 24(20).

Harackiewicz, J. M., Canning, E. A., Tibbetts, Y., Priniski, S. J., \& Hyde, J. S. (2016). Closing achievement gaps with a utility-value intervention: Disentangling race and social class. Journal of Personality \& Social Psychology, 111(5), 745-765. doi:10.1037/pspp0000075

Jones, A. \& Shindler, J. (2016). Exploring the school climate--student achievement connection: Making sense of why the first precedes the second. Educational Leadership and Administration: Teaching and Program Development, 27, 35-51. 
Karatzas Konstantinos, D. (2016). Lyndon B. Johnson and the Civil Right Act of 1964. Vestnik Volgogradskogo Gosudarstvennogo Universiteta. Seriâ 4. Istoriâ, Regionovedenie, Meždunarodnye Otnošeniâ, 21(3), 25-33. doi:10.15688/jvolsu4.2016.3.3

Kim, Y., Turner, J., \& Yazdian, L. (2014). Special issue: Looking back and moving forward: No Child Left Behind, Race to the Top, and Quality Teaching. Theory into Practice, 53(3), 173-175.

Kotok, S. (2017). Unfulfilled potential: high-achieving minority students and the high school achievement gap in math. The High School Journal, 100(3), 183. doi: 10.1353/hsj.2017.0007

Landmark Cases (2017). As retrieved from http://landmarkcases.org/en/landmark/cases/ brown_v_board_of_education\#Tab=Overview

Lawrence, A. (2012). Herbert Brownell, Jr.: The 'hidden hand' in the selection of Earl Warren and the government's role in Brown v. Board of Education. Journal of Supreme Court History, 37(1), 75-92. doi:10.1111/j.1540-5818.2012.01283.x

Logan, J. R. \& Burdick-Will, J. (2016). School segregation, charter schools, and access to quality education. Journal of Urban Affairs, 38(3), 323-345. doi: 10.1111/juaf.12246

Martin, M. M., \& Ngcobo, J. N. (2015). Social justice as a conduit for broadening curriculum access: Stories from classroom teachers. Perspectives in Education, 33(1), 87-99.

McCarthy, K. D. (2015). The battle of the branches: The impact of the judiciary and Title VI on desegregation in the American public school system. San Diego Law Review, 52(4), $967-$ 980. 
Missouri Department of Elementary and Secondary Education (2017). Retrieved from http://dese.mo.gov

Palardy, G. J., Rumberger, R. W., \& Butler, T. (2015). The effect of high school socioeconomic, racial, and linguistic segregation on academic performance and school behaviors. Teachers College Record, 117, 12.

Peterson, E., Rubie-Davies, C., Osborne, D., \& Sibley, C. (2016). Teachers' explicit expectations and implicit prejudiced attitudes to educational achievement: Relations with student achievement and the ethnic achievement gap. Learning and Instruction, 42, 123-140. doi:10.1016/j.learninstruc.2016.01.010

Rothstein, R. (2015). The racial achievement gap, segregated schools, and segregated neighborhoods: A constitutional insult. Race and Social Problems, 7(1), 21-30. doi:10.1007/s12552-014-9134-1

St. Louis Public Schools (2017). As retrieved from https://www.slps.org/domain/5110.

Taketa, K. (2016, November 16). Voluntary deseg programs to close for new students in 2024. The St. Louis Post-Dispatch. Retrieved from http://www.stltoday.com Voluntary Interdistrict Choice Corporation (2017). As retrieved from http://www.choicecorp.org Welton, A. (2013). Even more racially isolated than before: Problematizing the vision for "diversity" in a racially mixed high school. Teachers College Record, 115(11), 1-42. 


\section{Biographical Description:}

Amanda M. Lewis is an assistant principal at Lafayette High School in the Rockwood School

District in St. Louis, Missouri. She has interests in educational leadership, with an emphasis on equity and social justice. 


\section{CHAPTER SIX:}

SCHOLARLY PRACTIONER REFLECTION 


\section{Introduction}

Being a part of the Educational Leadership and Policy Analysis (ELPA) program at the University of Missouri-Columbia has been a tremendous experience. I have always considered myself to be a life-long learner, and truly value the knowledge and experience of others. Through the ELPA program, I had the ability to interact with caring adults from varying realms of education - small to large districts, pre-school to higher education - as well as members of the service community. I believe the following quote from Michelle Obama summarizes my involvement in the ELPA program. She says, "Through my education, I didn't just develop skills, I didn't just develop the ability to learn, but I developed confidence" (brainyquote, 2017). I believe that confidence is the underlying characteristic that I will take away from this experience. This confidence has allowed me to use my voice as a leader to make a difference in my school community.

\section{Influence as an Educational Leader}

As an administrator in a high school participating in the Voluntary Interdistrict Choice Corporation desegregation program, the research completed in this study was important and relevant to me as an educational leader. I have long been interested in the success rate of the VICC program, but became more so when the termination of the VICC program was announced in November 2016. At that time, I made the decision to focus my studies on the desegregation program to further understand the social and academic impact of the program on our students.

Being involved in this research opened my eyes to all aspects of the VICC program, and allowed me to evaluate the various practices used by our staff members. Over the past three years of study and evaluation, I had the opportunity to make suggestions and help implement programs that have supplemented the needs of our students. Our administrators, staff, and district 
officials have developed practices encouraging the inclusiveness of our VICC students in higher level courses. We have also brought in outside counselors, social workers, and community members to work with small groups of students to focus on social and academic achievement. These counselors have taught our young men and women the importance of African American history, self-esteem/self-worth, and the value in striving for a better future. These students have been selected for decision-making processes in the school and community. They have also gone on several field trips and college visits encouraging achievement and social success. Although academic excellence is a principal focus of our work in the high school setting, I am proud of the development of intentional connections and relationships between our students and staff.

\section{Influence as a Scholar}

During our first summer on campus at the University of Missouri-Columbia, one of our topics of study was diveristy. Diversity, social justice, and equity are areas that I am passionate about. Throughout our studies, I found myself generating ideas for professional development of the teachers in my building and became inspired to create practices to further develop our students as future leaders in our community.

While immersed in the ELPA coursework, I realized that the minority students in my building were not being challenged academically. This led to the initial topic I considered for study. If African American students participating in VICC were enrolled in our district since kindergarten, why were their enrollment numbers in honors or Advanced Placement (AP) courses so low? VICC students received the same level of education as their white counterparts, but did not have the drive to participate in challenging coursework. Through casual conversations with students and district staff members, I found that students did not enroll in upper level courses for three main reasons: 1) students in the class did not look like them, 2) peers or family members teased them, and 3) their friends were enrolled in regular education 
courses. I shared this information with my building principal and district representatives for the VICC program. Strategies were quickly put into place to encourage enrollment of African American students in our upper level honors and Advanced Placement courses. Today, we have a much larger presence of VICC students in our upper level courses and the trend continues to grow.

The passion to learn the "why" behind programs, ideas, and problems is an effect of the ELPA program that will be long-lasting in my life. Learning the appropriate steps for completing research has created a spark in my need to know more. While concluding this particular study of the social and academic impact on students in the VICC program, I had already begun developing plans to explore future areas of research. Involvement in the ELPA program has inspired me as a leader and scholar to do more for my school and educational community. 


\section{Bibliography}

BrainyQuote (2018). Retrieved from https://www.brainyquote.com

Chu, S. (2011). Perspectives in understanding the schooling and achievement of students from culturally and linguistically diverse backgrounds. Journal of Instructional Psychology, 38(3/4), 201-209.

Cope, G. (2015). "Something would develop to prevent it": North Little Rock and school desegregation, 1954-1957. Arkansas Historical Quarterly, 74(2), 109-129.

Diem, S. \& Brooks, J. (2013). Introduction to the issue on segregation, desegregation, and integration: from history, to policy, to practice. Teachers College Record, 115(11).

Downey, D. B., \& Condron, D. J. (2016). Fifty years since the Coleman report: Rethinking the relationship between schools and inequality. Sociology of Education, 89(3), 207-220. doi:10.1177/0038040716651676

Frankenberg, E., Diem, S., \& Cleary, C. (2016). School desegregation after parents involved: The complications of pursuing diversity in a high-stakes accountability era. Journal Of Urban Affairs, doi:10.1111/juaf.12309

Gamoran, A. \& An, B. (2016). Effects of school segregation and school resources in a changing policy context. Educational Evaluation and Policy Analysis, 38(1), 43-64. doi:10.3102/0162373715585604

Graglia, L. A. (2014). The Supreme Court's perversion of the 1964 Civil Rights Act. Harvard Journal of Law \& Public Policy, 37(1), 103.

Grooms, A. A. (2016). Money or diversity? An implementation analysis of the Voluntary Transfer Program in St. Louis, 1999-2009. Education Policy Analysis Archives, 24(20). 
Harackiewicz, J. M., Canning, E. A., Tibbetts, Y., Priniski, S. J., \& Hyde, J. S. (2016). Closing achievement gaps with a utility-value intervention: Disentangling race and social class. Journal of Personality \& Social Psychology, 111(5), 745-765. doi:10.1037/pspp0000075

Jones, A. \& Shindler, J. (2016). Exploring the school climate--student achievement connection: Making sense of why the first precedes the second. Educational Leadership and Administration: Teaching and Program Development, 27, 35-51.

Karatzas Konstantinos, D. (2016). Lyndon B. Johnson and the Civil Right Act of 1964. Vestnik Volgogradskogo Gosudarstvennogo Universiteta. Seriâ 4. Istoriâ, Regionovedenie, Meždunarodnye Otnošeniâ, 21(3), 25-33. doi:10.15688/jvolsu4.2016.3.3

Kim, Y., Turner, J., \& Yazdian, L. (2014). Special issue: Looking back and moving forward: No Child Left Behind, Race to the Top, and Quality Teaching. Theory into Practice, 53(3), 173-175.

Kirk, J. (n.d). Not quite black and white: school desegregation in Arkansas, 19541966. Arkansas Historical Quarterly, 70(3), 225-257.

Landmark Cases (2017). As retrieved from http://landmarkcases.org/en/landmark/cases/ brown_v_board_of_education\#Tab=Overview

Lawrence, A. (2012). Herbert Brownell, Jr.: The 'hidden hand' in the selection of Earl Warren and the government's role in Brown v. Board of Education. Journal of Supreme Court History, 37(1), 75-92. doi:10.1111/j.1540-5818.2012.01283.x

Logan, J. R. \& Burdick-Will, J. (2016). School segregation, charter schools, and access to quality education. Journal of Urban Affairs, 38(3), 323-345. doi: 10.1111/juaf.12246 
Martin, M. M., \& Ngcobo, J. N. (2015). Social justice as a conduit for broadening curriculum access: Stories from classroom teachers. Perspectives in Education, 33(1), 87-99.

McCarthy, K. D. (2015). The battle of the branches: The impact of the judiciary and Title VI on desegregation in the American public school system. San Diego Law Review, 52(4), 967980.

McDonough, I. K. (2015). Dynamics of the black-white gap in academic achievement. Economics of Education Review, 4717-33. doi:10.1016/j.econedurev.2015.03.007

Missouri Department of Elementary and Secondary Education (2017). Retrieved from https://dese.mo.gov

Miyasaki, R. (2015). Asleep at the school-bus wheel: The success and failure of school desegregation in San Jose United School District and how to save it. Golden Gate University Law Review, 45(2), 149-172.

O’Malley, M. P., Roseboro, D. L., \& Hunt, J. (2012). Accountability, fiscal management, and student achievement in East St. Louis, Illinois 1994-2006: Implications for urban educational reform policy. Urban Education, 47(1) 117-143. doi:

$10.1177 / 0042085911427741$

Palardy, G. J., Rumberger, R. W., \& Butler, T. (2015). The effect of high school socioeconomic, racial, and linguistic segregation on academic performance and school behaviors. Teachers College Record, 117(12).

Parsons, E. R., \& Turner, K. (2014). The importance of history in the racial inequality and racial inequity in education: New Orleans as a case example. Negro Educational Review, 65(1-4), 99-113. 
Peterson, E., Rubie-Davies, C., Osborne, D., \& Sibley, C. (2016). Teachers' explicit expectations and implicit prejudiced attitudes to educational achievement: Relations with student achievement and the ethnic achievement gap. Learning and Instruction, 42, 123-140. doi:10.1016/j.learninstruc.2016.01.010

Reber, S. J. (2010). School desegregation and educational attainment for blacks. Journal of Human Resources, 45(4), 893-914.

Rockwood School District (2017). Retrieved from www.rsdmo.org

Rothstein, R. (2015). The racial achievement gap, segregated schools, and segregated neighborhoods: A constitutional insult. Race and Social Problems, 7(1), 21-30. doi:10.1007/s12552-014-9134-1

St. Louis Public Schools (2017). Retrieved from https://www.slps.org/domain/5110 Thomas, D., Jacob, B., \& Lee, N. (2013). The effects of NCLB on school resources and practices. Educational Evaluation and Policy Analysis, (2), 252.

Voluntary Interdistrict Choice Corporation (2017). Retrieved from http://www.choicecorp.org Wasserman, L. M., Connolly, J. P., \& Steen, P. L. (2015). United States Supreme Court Justices' voting in systemic racial discrimination cases in education. Urban Lawyer, 47(1), 1.

Welton, A. (2013). Even more racially isolated than before: Problematizing the vision for "diversity" in a racially mixed high school. Teachers College Record, 115(11), 1-42. 


\section{APPENDIX \\ Journal Submission Confirmation}

\section{American Journal of Education \\ A Comparison of the Social and Academic Impact of High School Students Participating in Desegregation Programs to Their Peers}

\begin{tabular}{|c|c|}
\hline \multicolumn{2}{|l|}{ Manuecript Number: } \\
\hline Full Tnte: & $\begin{array}{l}\text { A Comparison of the Social and Academic Impact of High School Students } \\
\text { Participating in Desegregation Programs to Their Peers }\end{array}$ \\
\hline Short Tnte: & The Influence of Desegregation Programs on Student Success \\
\hline Arttcle Type: & Major Article \\
\hline Correeponding Author: & $\begin{array}{l}\text { Amanda Marie Lewis, M.Ed. } \\
\text { Lafayette High School } \\
\text { Ellisville, MO UNITED STATES }\end{array}$ \\
\hline \multicolumn{2}{|l|}{$\begin{array}{l}\text { Correeponding Author Secondary } \\
\text { Informetlon: }\end{array}$} \\
\hline Correeponding Author's Inettutton: & Lafayette High School \\
\hline \multicolumn{2}{|l|}{$\begin{array}{l}\text { Correeponding Author's Secondary } \\
\text { Inettution: }\end{array}$} \\
\hline Finst Author: & Amanda Marie Lewis, M.Ed. \\
\hline \multicolumn{2}{|l|}{ Finst Author Secondary Information: } \\
\hline Order of Authors: & Amanda Marie Lewis, M.Ed. \\
\hline \multicolumn{2}{|c|}{ Order of Authors Secondery Informatton: } \\
\hline Abstract: & $\begin{array}{l}\text { The purpose of this quantitative study compares social and academic impact data of } \\
\text { students enrolled in the St. Louis city desegregation program and their peers attending } \\
\text { neighborhood district schools. The research analyzed student data for grades } 9-12 \text {. } \\
\text { Attendance rates, drop-out rates, graduation rates, ACT scores, and End of Course } \\
\text { (EOC) exam scores were examined to determine if enrollment in the desegregation } \\
\text { program had a positive or negative impact on students. Study results found a } \\
\text { statistically significant positive relationship between students enrolled in the VCC } \\
\text { program and the social areas of attendance, drop-out, and graduation rates. A } \\
\text { statistically significant positive relationship was also found between students enrolled } \\
\text { in the VICC program and the academic areas of ACT and all but one area of the EOC } \\
\text { scores. Although academic data was closer in comparison than social data, the } \\
\text { relationship showed an overall positive statistical significance among VICC students. }\end{array}$ \\
\hline
\end{tabular}




\section{VITA}

Amanda Marie Lewis was born in Broken Bow, Nebraska; and moved with her parents to Cleveland, Tennessee, at the age of 2. She remained in Cleveland through graduation, then attended Southwest Missouri State University in Springfield, Missouri. While in Springfield, Amanda earned a Bachelor's degree in Middle School Education with an emphasis in mathematics and science. Shortly after graduating in 2001, Amanda married and relocated to Knoxville, Tennessee, where she taught $7^{\text {th }}$ grade mathematics at Bearden Middle School.

Amanda and her husband moved to Warrensburg, Missouri, in 2004 after her husband graduated from the University of Tennessee in Knoxville. Amanda taught mathematics and science at Holden High School, then $8^{\text {th }}$ grade science at Warrensburg Middle School. During the five years in Warrensburg, Amanda completed her Master's degree in Secondary Administration at the University of Central Missouri. Upon completion of her degree in 2009, Amanda's husband relocated them to St. Louis, Missouri.

While in St. Louis, Missouri, Amanda was offered a position as a high school assistant principal. During her tenure, she had the opportunity to loop with the students and experience all facets of the high school setting. In 2018, Amanda completed her Doctor of Education degree through the University of Missouri in Columbia, Missouri.

Amanda continues to work as an assistant principal at Lafayette High School in Wildwood, Missouri. She currently lives in Ellisville, Missouri. 